\title{
Escândalos, Marolas e Finanças: Para uma Sociologia da Transformação do Ambiente Econômico*
}

Roberto Grün

\section{INTRODUÇÃO}

\begin{abstract}
sociologia das finanças imbrica-se curiosamente com a sociologia A dos escândalos. Alterações no ambiente institucional e cultural que rege a atividade financeira das sociedades têm muitas vezes origens nas formas como elas reagem a escândalos. Talvez um dos exemplos mais expressivos dos tempos recentes tenha sido a reação norteamericana aos escândalos corporativos da Enron, WorldCom e Xerox, que levaram as autoridades dos Estados Unidos a rapidamente aperfeiçoar sua legislação societária. Dada a centralidade dos mercados financeiros norte-americanos na economia internacional do início do século XXI, suas conseqüências se espraiaram rapidamente pelo mundo todo, alterando significativamente a atuação de empresas e órgãos fiscalizadores nacionais (Coffee, 2002; Blair, 2003a; 2003b; Gates, 2003).
\end{abstract}

\footnotetext{
* As pesquisas das quais o presente texto é produto foram financiadas pela Fundação de Amparo à Pesquisa do Estado de São Paulo - FAPESP e pelo Conselho Nacional de Desenvolvimento Científico e Tecnológico-CNPq. Agradeço o apoio concedido pelas duas agências. Também agradeço aos pareceristas anônimos da DADOS as críticas e sugestões feitas à versão original do texto. Em um momento anterior, o mergulho na bibliografia e na problemática aqui desenvolvida foi possível com a ajuda de discussões estabelecidas com Patrick Champagne, Monique de Saint-Martin e Afrânio Garcia em Paris, em uma estada financiada pela Coordenação de Aperfeiçoamento de Pessoal de Nível Superior - Capes. Agradeço aos colegas e à agência a facilitação e a troca intelectual.

DADOS - Revista de Ciências Sociais, Rio de Janeiro, Vol. 51, no-2, 2008, pp. 313 a 352.
} 


\section{Roberto Grün}

De forma geral, os escândalos podem produzir ondas de choque que impulsionam e obrigam grupos de agentes sociais a revirar seus tool kits de repertórios culturais para atacar seus adversários ou para se defender deles (Garrigou, 1993; Thompson, 2000; De Blic, 2005). Nesses embates, testam-se e acabam sendo descobertas sensibilidades sociais e inventados conteúdos inesperados. O Brasil atravessou, nos anos 2005-2006, uma sucessão de escândalos, que começou com o caso Waldomiro ${ }^{1}$, teve seu auge no episódio do mensalão ${ }^{2}$ e perigeu no dossiê-gate ${ }^{3}$, desembocando na reeleição do presidente Luiz Inácio Lula da Silva. O conjunto de chacoalhadas produzido nessa seqüência de eventos teve o efeito paradoxal de fazer emergir o tema das privatizações, que parecia definitivamente resolvido na sociedade brasileira. A privatização das empresas estatais era um ponto essencial da estratégia de ultrapassar a herança do varguismo, proposta pelo governo de Fernando Henrique Cardoso. Para isso, seu principal aliado foram os braços do sistema financeiro interessados nos diversos tipos de negócio que a privatização ensejou. Somaram-se assim os interesses políticos e as sensibilidades ideológicas dos políticos no poder, naquele momento, que visavam enfraquecer o que enxergavam ser ao mesmo tempo as fontes de poder de seus adversários petistas e as principais razões da estagnação econômica do país com os interesses mais propriamente materiais de toda a galáxia de atores que opera a transição da economia brasileira para uma contemporaneidade balizada pelos mercados financeiros. A acolhida que essa empreitada recebeu na mídia e nos opinion makers foi tão positiva que a idéia de privatização dava a impressão de ser um componente já naturalizado da sociabilidade brasileira contemporânea. No entanto, o "escândalo político-financeiro" e o processo eleitoral que o sucedeu revelaram que continuava aberto o conflito cultural que subsume as atividades econômica e financeira da sociedade (De Blic, 2003; Grün, 2004a; 2007b).

O questionamento - ainda que titubeante - da idéia de que a privatização das empresas estatais e dos serviços públicos em geral seja um processo correto e, por isso, inquestionável atenta contra o bom senso prevalecente nos anos que se seguiram ao ocaso do milagre econômico do início dos anos $1970^{4}$. Temos assim que a recente seqüência de acontecimentos produziu um efeito simbólico relevante, impactando a vida pública (Gois, Jungblut e Damé, 6/1/2007; Nossa e Monteiro, 6/1/2007) e, em decorrência, também o espaço das finanças. Mudam-se os limites do que é discutível nas esferas econômica e política e, conseqüentemente, o jogo das finanças também se altera, modificando 
as estratégias, os riscos e os cálculos habituais. Colocam-se assim, subitamente, os limites da autonomia de um campo social cujos atores parecem hegemônicos na sociedade brasileira, revelando uma variante nacional do padrão de relacionamento geral da esfera financeira com os demais segmentos das sociedades contemporâneas (De Goede, 2004; 2005).

Em termos analíticos, estamos diante de uma "janela" que nos permite entender as relações entre as finanças e a sociedade, em especial sobre as fontes, principalmente sobre os limites do poder aparentemente inaudito que elas adquiriram e os fundamentos culturais dessa configuração. As formas como as finanças se desenvolvem dependem do substrato cultural da sociedade e dos conflitos que a atravessam nessa esfera. Como a chamada "financeirização" está no centro da doxa econômica que vige no Brasil contemporâneo, é interessante explorar sua base, ainda pouco esclarecida, tanto analiticamente quanto em seu potencial transformador ou conservador. Na configuração criada na base pela financeirização e catalisada pelos escândalos e pela necessidade de os partidários do governo de Luiz Inácio Lula da Silva se diferenciarem das elites tradicionais que os rejeitavam, observamos uma tendência à "financeirização de esquerda". Nela, os petistas e aliados acabam impulsionando a difusão de novidades na esfera financeira que beneficiam suas clientelas tradicionais ou novas. Dessa maneira, ao mesmo tempo que aumentam o escopo e a legitimidade da dominação financeira de maneira geral, também é esculpido um patamar mais sólido para os posicionamentos dos desafiantes petistas no campo do poder brasileiro. Na conjuntura do período, se os escândalos ferem gravemente os petistas, a lembrança da privatização se revela uma arma contra seus detratores. O prosseguimento dessa pista deflagra toda uma seqüência de possibilidades cognitivas, políticas e econômicas que assinalam claramente a dependência da esfera financeira aos condicionantes culturais e políticos da sociedade. A partir dessa pista, faz-se uma leitura neste artigo assumidamente viesada pela literatura sobre escândalos políticos, buscando nela indícios para apresentar algumas das formas como o conflito cultural se relaciona com a robustez, o enfraquecimento ou a possível transformação da doxa econômica. Nesses termos, ainda que sua pretensão específica seja a análise das alterações simbólicas que recolocam a legitimação da esfera financeira, os escândalos talvez interessem também para o entendimento da "guerra política" que irrompe no Brasil entre 2005 e 2006. Eles deflagram a áspera contenda que desemboca nas eleições presidenciais de 2006, nas 
quais o presidente Lula enfrenta o peessedebista Geraldo Alckmin. No primeiro turno, ocorrido em 1ํ de outubro de 2006, Lula é o primeiro colocado, com 48,61\% dos votos contra 41,64\% de Alckmin. Contudo, as últimas pesquisas indicavam, nas estatísticas, um viés de alta para Alckmin e de baixa para Lula, animando os seguidores do peessedebista. Seguiu-se a campanha do segundo turno, que terminou nas eleições de 29 de outubro de 2006, na qual Lula prevaleceu atingindo a marca de $60,83 \%$ contra $39,17 \%$ de seu adversário.

\section{A SOCIOLOGIA DOS ESCÂNDALOS}

Na análise sociológica dos escândalos, estes são tidos como um dos fatores mais relevantes ou presentes para alterar ou criar novas sensibilidades sociais. Os escândalos podem começar nas mais diversas esferas da vida social, mas tendem a desaguar na esfera política. Por isso, se quisermos avaliar suas causas, processos e resultados, a arena política é um local privilegiado para focar uma análise mais geral. Parto, assim, da esfera política para depois voltar ao espaço empírico das finanças.

Escândalos podem ser compreendidos de diversos ângulos. Um deles fala do escândalo como forma operacional ou recurso estratégico: nesse caso, é classificado, ao lado de passeatas, atos públicos, abaixo-assinados, greves de fome etc., como uma das técnicas possíveis de mobilização e manifestação. Não por acaso, a literatura que expõe essa vertente fala em "escandalização" (Garrigou, 1993; Offerlé, 1994; Adut, 2004). Outra linha teórica trata o fenômeno como "revelador": o escândalo revela a estrutura moral da sociedade ou de parte dela. Se ele prospera, estamos diante de um conteúdo moral integralmente compartilhado; do contrário, as normas que teriam sido conspurcadas não são avaliadas da mesma maneira na sociedade em questão. Aqui estamos no centro da tradição durkheimiana. Uma terceira linha de análise, derivada da vertente que trata o fenômeno como "revelador", procura conhecer os efeitos dos escândalos na criação de novas normas sociais. Nesse caso, os verdadeiros escândalos são aqueles que geram energia social suficiente para alterar alguma legislação ou regulamentação. Nessa linha, auto-intitulada "pragmática", as manifestações que não atingem o estágio crítico da mudança inscrita em um código não seriam verdadeiros escândalos, mas apenas tentativas fracassadas (De Blic, 2005). 
Na primeira vertente, o foco deste artigo é dirigido para os agentes que produzem os eventos e para as formas de mise-en-scène que empregam a fim de tornar pública a transgressão. O campo político passa a ser um cenário no qual indivíduos e técnicas são testados em sua habilidade e capacidade de produzir escândalos. Uma linha paralela, diretamente inspirada em Bourdieu, leva em conta a produção de eventos políticos como uma técnica e também avança uma síntese. Ela mostra como a relação entre as distribuições de capitais culturais e sociais poderia explicar as capacidades diferenciais de conhecer e manipular eficientemente as técnicas necessárias para tornar públicos os conteúdos considerados escandalosos e utilizá-las de acordo com suas posições relativas no tabuleiro político (Champagne, 1984; 1990). Desafiantes acionariam esse recurso para quebrar a doxa dominante com respeito às qualidades "reais" ou desejadas para os líderes políticos. A estrutura retórica mais típica dos desafios consiste em denunciar propósitos individuais dos políticos que estariam sendo escondidos sob uma falsa máscara de devoção ao interesse coletivo (Boltanski, Darré e Schiltz, 1984). Quando se trata de cobrar promessas não realizadas, as assimetrias de capitais teriam um efeito limitado na capacidade de denúncia, mas, quando se trata de enunciar e tentar instituir novas regras, aí elas fariam valer toda a sua força. A possibilidade de realizar esse trabalho de inscrição de novos conteúdos na sociedade é fortemente dependente de uma posição privilegiada do "empreendedor" na distribuição de capitais cultural e social (Duby, 1978; Bourdieu, 1981; 1992).

A abordagem estratégica foi explicitada na análise dos escândalos ocorridos na França quando da presidência Mitterrand, na qual o então presidente foi implacavelmente acusado de estar envolvido em diversas malversações financeiras por meio de um processo de retroalimentação entre seus adversários políticos e parcela relevante da mídia desse país (Garrigou, 1992). Independentemente dos "verdadeiros" dotes morais de cada um dos indigitados, salta aos olhos a analogia entre a estrutura retórica da acusação a Mitterrand no final dos anos 1980 e aquela feita a Lula nos anos 2005-2006. Corroborando a análise de Boltanski, Darré e Schiltz (1984), em ambos os casos a estratégia retórica dos escandalizadores fazia menção a um estado de pureza econômica que os imputados diziam e deveriam ostentar, mas que os fatos revelados denotavam ser falsa.

É interessante notar a bem provável existência de um padrão internacional desenvolvido nos últimos vinte anos: presidentes eleitos pela 
esquerda do espectro político são sistematicamente acusados de exibir uma moral pública elevada que é falsa, a qual, por sua vez, esconderia a verdadeira moral privada, nada recomendável. Nos países latinos, a baixa estatura moral é mais associada à escroqueria econômica; nos anglo-saxões, a condutas sexuais reprováveis (Thompson, 2000; Chantal, 2001; Garrigou, 1992). Em ambos os casos, há uma estrutura retórica bem definida para as acusações, que apela para o incômodo causado pela transgressão da doxa cognitiva, social e política. Popularmente falando, a idéia que se tenta passar no combate político de reconquista conservadora norte-americana e francesa ${ }^{5}$ é o tradicional "quem nunca comeu melado quando come se lambuza". Cria-se assim o fenômeno que Thompson descreve como "as lutas simbólicas em torno da reputação e da confiança que devemos, ou não, depositar nos personagens em questão" (2000:103) $)^{6}$. Talvez, mais interessante do que nos atermos ao fascínio ou ao repúdio que esse processo deflagra, seja relevante notar sua lógica social e cultural. Os indivíduos oriundos das classes dominantes tradicionais ou assimilados tendem a fornecer a maior parte dos políticos da situação, enquanto que os desafiantes costumam vir de classes médias em ascensão. Assim, esses últimos portam, mais provavelmente, elencos de propriedades individuais e coletivas ainda não totalmente legitimadas e habitus menos preparados para jogos de sociedade. Não é por acaso que eles correm um risco maior de deslegitimação do que seus adversários (Bourdieu, 1979; 1981).

Na análise da energia social necessária para "produzir o efeito escândalo", podemos catalogar os eventos que entram nessa rubrica em dois tipos: os que pretendem construir novas institucionalidades e aqueles que têm no horizonte o simples respeito a uma norma já existente, mas conspurcada ou esquecida (Adut, 2004). Os indivíduos que deflagram o primeiro tipo são recobertos pela rubrica de "empreendedores morais" (Becker, 1963; Gusfield, 1986). Nesse caso, os "produtores de escândalos" agiriam movidos por algum tipo de indignação, a exemplo dos formadores das ligas pela temperança do mundo anglo-saxão (Gusfield, 1986). Oálcool foi um companheiro da humanidade durante milênios. Proibir seu consumo importa em alterar habitualidades muito arraigadas, e essa nova norma só poderia ser acatada à custa de um imenso trabalho de "re-apresentação" de suas qualidades e problemas (Hacking, 1983; 1995; 1998; Goody, 1997). Os exemplos de dissolução moral, observados e propagandeados pelos empreendedores da temperança, forneceriam combustível ao mesmo tempo para suas convicções e para o trabalho de apresentação de argumentos para sua proibi- 
ção. Contudo, a mais intensa campanha moralizadora não foi capaz de inscrever duravelmente a norma da proibição, ainda que ela tenha permanecido em alguns grupos.

Feministas e ecologistas seriam os representantes modernos mais típicos do gênero de empreendedorismo radical que consiste em inscrever novos conteúdos morais na sociedade. Os atos paradoxais, promovidos para a causa que abraçaram, produziriam o capital simbólico necessário para conferir verossimilhança à sua devoção e legitimidade à sua pregação. Esses empreendedores são indivíduos capazes de realizar performances inusitadas e de chamar a atenção da sociedade para elas. Assim, a lógica social da produção desse capital simbólico aponta para a transubstanciação de seus capitais cultural e social originais. Evidentemente, trata-se de empreendimentos à Schumpeter. Afinal, esses agentes correm vários riscos em suas empreitadas, desde sua ridicularização pelos establishments até riscos concretos de vida, passando pela "simples" falta de reconhecimento social do trabalho realizado. Além disso, a reputação produzida nesse esforço está sempre ameaçada por denúncias que expõem a "falsa devoção" ou mesmo a "devoção apenas relativa" desses empreendedores (Bourdieu, 1980). Daí a rigidez que esse gênero de ator social costuma apresentar na arena pública: a gestão do capital simbólico recém-conquistado é fundamental e complexa, pois está sujeita não só à difamação da não-observância dos princípios apregoados como também ao processo de ridicularização tanto da nova norma quanto da postura intransigente (Douglas, 1996).

O outro tipo de escândalo é aquele que faz menção ao não-cumprimento de normas, regras ou legislações já estabelecidas. No Brasil, os empreendedores mais típicos dessa modalidade são os novos agentes do campo jurídico, como o Ministério Público, além dos setores da imprensa que os divulgam ${ }^{7}$. O ato de tornar pública uma transgressão praticada por agente dotado de alta legitimidade ou de proteção institucional -e, portanto, romper a inércia que o protege - é a matéria-prima típica de que se nutre essa modalidade de escandalização. Como no exemplo francês, uma das conseqüências mais claras dessa mobilização "escandalizante" das novas agências jurídicas é o aumento do status do grupo quando comparado a outros setores do Executivo ou do Judiciário; e, correlativamente, o aumento de visibilidade do agente especificamente responsável pelo escândalo em questão. Em uma sociedade em que os espaços político e judiciário são tidos como lenien- 


\section{Roberto Grün}

tes para os acusados dotados de bom relacionamento social, a conspurcação da quebra dos limites do corporativismo profissional seria justificada pelo ganho de eficiência na tramitação dos processos (Adut, 2004).

As duas formas de produção de eventos políticos, normalmente analisadas nelas mesmas, têm sua eficiência dependente da ressonância que ganham na mídia. Faz-se necessário considerar as formas por meio das quais a ligação é realizada ou deixa de sê-lo. Champagne (1984; 1990; 1996) e Champagne e Marchetti (1994) analisam diversas estratégias usadas por grupos de manifestantes para produzir a sintonia com os meios de comunicação e, dessa forma, fazer avançar suas causas. De um lado a produção de eventos com formato adequado para serem bem notados pela mídia; de outro, um relevo social no espaço da mídia no qual algum grupo de jornalistas tenha interesse específico em noticiar e, assim, conferir vida social ao acontecimento produzido pelos empreendedores. Essa dinâmica pode ser decalcada para englobar nossos produtores de escândalos. A mídia confere vida social aos escândalos noticiando-os. Quando ela o faz? Escândalos são um gênero de matéria-prima jornalística muito apreciado; afinal, são eles que excitam a demanda pelos produtos jornalísticos. Contudo, há de se questionar: quando um acontecimento recebe essa catalogação? Quando ele se destaca da normalidade? Quando um "possível escândalo" se torna pauta obrigatória na imprensa, deflagrando uma concorrência pela "melhor cobertura" ou pela - sociologicamente esperada - "descoberta de fatos inéditos e comprometedores"? Afinal, defrontamonos cotidianamente com situações que contrariam nossas convicções, ou nas quais enxergamos graves problemas para o futuro da sociedade, sem que passemos ao ato de denunciá-las. Mais ainda: quando a denúncia pessoal se transforma em clamor coletivo?

Na análise da lógica social que move o espaço jornalístico, Schudson $(1989$; 1992) lembra-nos o papel simbólico seminal dos eventos políticos e midiáticos ocorridos em torno do caso Watergate. Desde aquele momento a mídia norte-americana passou a considerar o "jornalismo investigativo" a atividade mais nobre de sua profissão, e não mais o jornalismo no qual a cobertura política era uma variante das amenidades da coluna social. A partir daquele escândalo, o protótipo de jornalista passou a ser um descobridor de verdades escondidas pelas conveniências dos poderosos. Ao revelar à sociedade as entranhas e artimanhas do poder, o jornalista se torna um elemento essencial do equilí- 
brio democrático (ibidem); e o escândalo passa a ser assim o validador maior da ação dessa atividade profissional: a consagração do bom jornalista é o papel central que seus colegas lhe conferem na produção de um "bom escândalo".

A fase de inflexão do jornalismo norte-americano convergiu com a redemocratização brasileira dos anos 1970 e 1980. Em seu âmbito nacional, o processo adquiriu uma dinâmica de afirmação profissional desencadeada, em parte, pela consolidação dos cursos universitários de jornalismo. O resultado foi uma entrealimentação que gerou o processo local de reconfiguração da profissão e de sua importância relativa aos "outros poderes". Um bom exemplo da forma como esse processo adquiriu, na realidade brasileira, tanto a substância das denúncias quanto a atividade autocelebratória da imprensa pode ser encontrado em 10 Reportagens que Abalaram a Ditadura, de Molica (2005).

Dificilmente o "script norte-americano" por si só poderia explicar o processo. É flagrante que a configuração brasileira se nutre também do processo paralelo que ocorre no campo jurídico, no qual as procuradorias ganharam o poder que hoje ostentam. A homologia de posições (Bourdieu, 1984) acabou gerando uma sintonia na qual os métodos e propósitos de um grupo profissional alimentam e também dependem da ação, aparentemente concatenada, do outro. Estamos assim diante de uma realidade nuançada que guarda analogias com Estados Unidos e França, dois países dos quais buscamos bibliografia e que têm peculiaridades marcantes. No mais, ainda que os analistas explícitos dos "escândalos como forma política" não explorem a questão, as transformações no campo jornalístico francês também são explicativas, como mostram Champagne e Marchetti (1994), bem como a ação de braços do campo jurídico norte-americano, sobretudo a ação mais recente do promotor especial Kenneth Starr no caso Clinton e Lewinsky ${ }^{8}$. Muito provavelmente, uma exploração da literatura sociológica de outros países apontará outros paralelos. Estamos, portanto, diante de uma seqüência de transformações análogas dos diversos campos do poder nacionais. Em uma primeira dimensão, temos as concorrências internas pela primazia em cada um dos campos (midiático, jurídico, político); em uma segunda, a cooperação objetiva dos agentes situados em cada um dos campos parcialmente autônomos a fim de realçar a importância de sua profissão ou ocupação diante das outras. As refregas internas de cada campo têm um claro limitante no enjeu das lutas: os jogos internos de cada campo tendem a estabelecer como objetivo a melhor 
maneira de realçar a importância do métier em face dos demais instrumentos de regulação; assim, qualquer disputa que ponha em risco essa expectativa é rapidamente enquadrada e debelada. Finalmente, temos o impacto do resultado das lutas e cooperações de cada campo nos outros dois produzindo respostas obrigatórias e abrindo novas concorrências internas pela "melhor resposta" que retroalimentam e dão novo sentido às dinâmicas internas. Como quer Bourdieu (1989), essas evidências indicam novas relações entre mídia, campo jurídico e espaço político, sugerindo o aprofundamento analítico da idéia de "alongamento dos circuitos de legitimação" e o refinamento de instrumentos empíricos para realizar essa tarefa intelectual complexa. Esses instrumentos devem ser capazes de dar conta dessas transformações, que são multidimensionais e dotadas de interatividade forte e pouco conhecida não só em cada um dos espaços mas também entre os espaços (Dobry, 1986).

\section{RELAÇÃO ENTRE ESCÂNDALOS E CONSPIRAÇÕES}

Um ponto de contato tenso entre a abordagem estratégica e as normas aparece no tema das conspirações. Os indivíduos e grupos que são objeto de escândalo freqüentemente acusam a existência de conspirações de detratores que estariam por trás das denúncias de que estão sendo vítimas. Uma vez que existe toda uma galáxia de artefatos culturais que utilizam o tema das conspirações em seus enredos, é fácil criar alguma verossimilhança para esse gênero de explicação. O sucesso comercial de obras como O Código Da Vinci ${ }^{9}$, de Dan Brown (2004), inscrito em uma linhagem contínua de artefatos culturais, que vem de $O$ Despertar dos Mágicos (Pauwels e Bergier, 1975, 11a edição), tanto revela quanto ajuda a intensificar essa predisposição (Taguieff, 2005). Na esfera pública, a conspiração, entendida como uma forma retórica estabelecida, faz parte dos repertórios políticos ocidentais desde pelo menos a difusão européia dos "Protocolos dos Sábios do Sion", famoso apócrifo anti-semita, produzido pela polícia secreta czarista, que relata uma "evidente" conspiração judaica para dominar o mundo (Cohn, 1967; Girardet, 1986). Esse artefato pode ser considerado o protótipo do gênero e, não por acaso, circula ainda hoje em diversos locais, sobretudo em países de maioria muçulmana cujos governos estão em oposição direta ao Estado de Israel, além de ter ganho uma sobrevida robusta no Ocidente a partir da nova galáxia virtual da internet ${ }^{10}$ (Lewis, 1986; Erner, 2005). 
A estrutura retórica mais recente da denúncia de conspirações faz menção à existência de conluios secretos entre os diversos setores das elites do país ou de países concernidos. Todos esses grupos - portanto, um conjunto de atores muito mais amplo do que os "sábios do Sion" estariam unidos na empresa de esconder alguma verdade que os desfavorecesse e/ou de passar alguma versão da realidade que lhes fosse vantajosa. Evidentemente, os prejudicados por essas ações seriam os estratos populares da sociedade - o "Zé Povinho" do imaginário luso-brasileiro (Medina, 1992).

Podemos dizer que, na construção social do escândalo, a conspiração é o oposto da indignação. Do lado atacante, o esforço, consciente ou não, é para produzir um efeito de união geral em torno da defesa da norma supostamente infringida. Essas descargas de energia social podem ser analiticamente assimiladas aos rituais produtores de coesão social que fornecem a base da sociologia da religião de Durkheim. Nessa interpretação, os escândalos podem ser considerados uma das muitas "missas modernas" que produzem e celebram a coesão social das sociedades, supostamente leigas, da modernidade (Schudson, 1998; Collins, 2004). Os celebrantes desses artefatos sociais de efeitos análogos ao da missa nas sociedades tradicionais se qualificam para simbolizar a coesão social (aparentemente?) orgânica como novos sacerdotes da virtude pública. Imprecando e encarnando as normas sagradas que foram desafiadas, nossos empreendedores morais promovem assim o que poderíamos chamar de "efeito de missa" - a descarga e a concentração de energia social necessárias para deflagrar e manter um escândalo na esfera pública (Collins, 2004).

A idéia da conspiração, que vê no processo mencionado apenas os interesses dos "simbolizadores", acaba desdenhando da missa e de seus efeitos sociais, pondo todo o peso do processo apenas em seus sacerdotes. Mutatis mutandis, estamos diante de uma variante da velha crítica que vê na religiosidade pentecostal apenas a ganância do pastor. Ela pode ou não existir, mas insistir na centralidade desse eixo explicativo implica não perceber os efeitos do culto sobre aqueles que o acompanham, além de atribuir-lhes uma capacidade infinita de agir no sentido contrário a seus interesses. Como, vista de fora do círculo dos crentes, a magia parece simplesmente um engodo, não é de admirar que seus efeitos não sejam notados por aqueles que não participam da reprovação da norma conspurcada. Se a isso acrescentarmos que a explicação estratégica se adapta mais a disposições intelectuais na órbita da hipóte- 


\section{Roberto Grün}

se subsocializada para o comportamento humano, a falta de sensibilidade teórica para perceber fenômenos análogos à missa é um traço esperado, ainda que não obrigatório, dos analistas que esposam essa vertente (Rieder, 1990).

O desenvolvimento da idéia de conspiração também denota um ponto de vista sobre a realidade social que oblitera as nuances dos campos profissionais e do campo do poder. Analiticamente, essa idéia se forma e se mantém pela retenção da noção althusseriana de "aparelho", de algumas versões da idéia de "sistema" ou variantes, que enxergam a mídia, o patronato, o espaço político e o judiciário como blocos coesos e exclusivamente a partir dos resultados externos de suas ações (Bourdieu, 1981; Bohn, 2006). Sociologicamente, esse costuma ser o ponto de vista de indivíduos e grupos postos à margem dos processos de decisão social, em geral pertencentes a seitas religiosas ou políticas (Douglas, 1996). Como nos explica Mary Douglas, as visões conspiratórias são produzidas em ambientes sociais apartados - em geral de maneira consciente - da cultura da sociedade inclusiva. Apoiada em Fleck (1979) [1935], Douglas (1986) avança na hipótese durkheimiana e mostra como as crenças pessoais são engendradas e mantidas coletivamente a partir de uma decisão prévia de pertencimento a determinada comunidade. Uma vez tomada essa decisão primeva, a crença na "família de pensamento", ou "paradigma", vira uma decorrência automática ${ }^{11}$. Essa predisposição social acaba agindo principalmente sobre membros de grupos estigmatizados que adentram no campo do poder, no qual são recebidos apenas parcialmente. Uma conclusão parcial é que a maior ou menor adesão ao "delírio conspiratório" dá boa medida da ligação ao grupo de origem ou da adesão à elite dominante.

Podemos tentar compor os pontos levantados por Douglas com aqueles que Bourdieu põe na discussão. É lícito deduzir que os habitus produzidos em enclaves sociais são incapazes de fazer inferências probabilísticas razoáveis sobre as formas de convivência usuais em outros ambientes cujas premissas são diferentes ou mesmo abominadas por aqueles que habitam o espaço apartado (Bourdieu, 1958; 1974). É assim que esses grupos dificilmente desenvolveriam a percepção da possibilidade muito reduzida de haver uma orquestração consciente de indivíduos, grupos e setores com interesses e percepções tão diferenciados como a mídia, o campo jurídico e o político, cada qual com seus integrantes ao mesmo tempo em concorrência interna no espaço específico e em concorrência externa no campo do poder. Por isso, as interpretações hegemônicas dos eventos, resultado da concorrência permanente 
em cada espaço e no espaço dos espaços que é o campo do poder, quando adversas à sensibilidade dos indivíduos locados nos enclaves, são vistas como uma atividade orquestrada ${ }^{12}$.

\section{Duas Missas}

A crença na conspiração produz, ela mesma, um "efeito de missa" inverso naqueles que participam do círculo, já previamente posicionados no enclave. Acreditando na conspiração, eles reagem ao que enxergam como perigo produzindo mobilizações que podem gerar efeitos sociais. Como esse mecanismo é também uma intervenção efetiva na cena política, mas que depende da legitimidade de quem o emprega, jamais saberemos se os integrantes do campo do poder que o utilizam acreditam "sinceramente" nas conspirações que alardeiam. No entanto, sabemos que: 1) muitas vezes, atores políticos relevantes têm interesse na criação de verossimilhança para as conspirações; 2) como nos ensina Mary Douglas, o convívio com suas bases de apoio, e no ambiente político, os induzem a se postar no círculo da crença. Assim, juntando as pontas, poderíamos falar de "conspiração como empreendimento e também como convicção", bem como da enorme dificuldade analítica de destrinchar essas motivações e crenças.

Em outro plano, há a mídia do pós-Watergate, que consagrou o padrão de excelência do jornalista produtor de escândalos. Da mesma forma, as comissões parlamentares de inquérito e as investigações do Judiciário operam um efeito análogo no seio dos respectivos poderes, premiando aqueles que se destacam nesses eventos através das vantagens que o direcionamento dos holofotes da mídia lhes acarreta. Como as estruturas narrativas usuais para relatar os eventos costumam personificar sua eclosão e desenvolvimento nos heróis e vilões disponíveis (Manoff e Schudson, 1986), as teses conspiratórias têm outro combustível para ganharem verossimilhança. Considerando que privilegiar a ação em detrimento da estrutura é uma característica esperada dos agentes inseridos no espaço político, eles tendem a esposar a vertente estratégica mesmo quando estão do lado da acusação, ainda que, por vezes, o oportunismo retórico os faça justificar suas ações diferentemente para o público externo (Bourdieu, 1981).

Diante da eclosão de algum escândalo, os dois gêneros de explicação acabam vindo à luz por representarem boas retóricas: o primeiro para quem se defende e o segundo para quem acusa. Misturando-se aos protagonistas dos fenômenos a serem explicados, não é espantoso que os 


\section{Roberto Grün}

dois veios explicativos encontrem rapidamente seus limites. Sendo os "empresários" os responsáveis pelos escândalos, por que estes não são permanentes? Sendo a infringência das normas sociais o que produz os escândalos, por que a infinidade de situações potencialmente escandalosas que presenciamos cotidianamente não se tornam "verdadeiros" escândalos?

Outra armadilha empírica que confere veracidade à explicação da conspiração reside na constatação da existência permanente e estrutural de conspiradores mais ou menos profissionalizados e dispostos a qualquer empreitada. Essa constatação não é surpreendente se considerarmos que estamos em um espaço social altamente profissionalizado, no qual diversas especialidades podem produzir e encontrar demanda para seus serviços, tornando cada vez mais complexa a divisão interna do trabalho, na qual a concorrência induz à busca de novas especializações e à sua justificação. Por fim, sua hipóstase leva ao que Aldrin (2005:138) chama, apropriadamente, de "armadilha do estrategismo".

\section{FACE BRASILEIRA DO FENÔMENO INTERNACIONAL}

É interessante observar no Brasil recente a emergência da hipótese da conspiração no debate político a partir, aparentemente, do centro do governo federal. Após o escândalo do mensalão, falou-se na estratégia das elites de "desconstruir Lula e o Partido dos Trabalhadores - PT". Em estrita continuidade, a convergência de pontos de vista da mídia e da oposição política sobre o dossiê-gate, tido como negativo para o PT e para Lula, foi lida por porta-vozes governamentais como uma conspiração orquestrada para prejudicar os prospectos eleitorais do candidato Lula. Em um primeiro momento, a "desconstrução" foi atribuída ao banqueiro Daniel Dantas, caracterizado como uma versão tropical e contemporânea do plutocrata do início do século XX (Grün, 2007b). Ele, por intermédio de seu preposto Roberto Jefferson, teria deflagrado o escândalo do mensalão porque o governo Lula estaria preterindo seus interesses econômicos para privilegiar os dirigentes dos fundos de pensão. Essa versão, rapidamente esquecida, teve seu momento de glória no final do primeiro semestre de 2005. Ela apareceu em uma publicação considerada pró-petista (Folha Online, 30/5/2006; Lirio, 3/8/2005), mas percorreu o ciclo de legitimação, passando também pelo centro do establishment da mídia, até se desvanecer (Souza e Alencar, 23/8/2005; Chagas, 31/7/2005). 
Paralela e incrementalmente, a idéia de conspiração geral começou a ganhar força, pois estaríamos diante de uma vasta conspiração, abarcando diversos segmentos da imprensa, do sistema político e das elites econômicas. Como quer um texto muito citado por aqueles que partilham da idéia:

\begin{abstract}
A imprensa trabalha para desconstruir Lula, para deixá-lo só, sem uma base partidária e sem condições de consolidar uma aliança que lhe desse a possibilidade de lutar pela reeleição. Quer lhe ensinar uma lição de História: lugar de operário é ao pé da máquina. Quer fazê-lo ver que a eleição de 2006, mesmo que ele chegue lá com a popularidade preservada, será um massacre, porque a massa vai votar naquele que ficar bem na TV (Costa, 25/7/2005).
\end{abstract}

Posteriormente, quando é deflagrado o escândalo da compra do dossiê anti-Serra, a idéia de conspiração das elites volta à tona. Nas palavras do coordenador de campanha de Lula, diante das fotos que seriam do dinheiro apreendido no dossiê-gate:

Não creiam que nós não percebemos, por mais sutis que possam parecer, o encadeamento de fatos com fotos e imagens de uma maneira deliberada. Editar não é esconder, cortar informações de extrema relevância num momento vital, como fizeram no caso do delegado. Há jornalistas que criticaram o governo quando este tentou impedir a divulgação das fotos, por entender ser esta uma maneira de interferir na eleição, na reta final, mas foram jornalistas que exerceram a censura em relação a vários fatos, inclusive no caso do delegado - disse Marco Aurélio [Garcia] (O Globo Online, 2/10/2006).

Trabalhado em uma versão erudita, mas que não perde o conteúdo causídico, o ponto de vista dos petistas busca legitimidade intelectual em um livro de Lima (2006), em que a formulação é então exposta da seguinte forma:

Nosso argumento é que antes mesmo da revelação pública das cenas de corrupção nos Correios, em maio de 2005, o "enquadramento" da cobertura que a grande mídia fez, tanto do governo Lula como do Partido dos Trabalhadores (PT) e de seus membros, expressava uma "presunção de culpa" que, ao longo dos meses seguintes, foi se consolidando por meio de uma narrativa própria e pela omissão e/ou pela saliência de fatos importantes (ibidem:14). 


\section{Roberto Grün}

A idéia de conspiração que prosperou no Brasil da segunda metade do primeiro mandato presidencial de Lula apresentou assim tanto a versão "restrita", na qual Daniel Dantas, um indivíduo poderosíssimo, teria a capacidade de produzir a derrocada do governo federal, quanto a versão "ampla", na qual esse papel é atribuído a um conluio geral das elites operacionalizado pela mídia. Observa-se assim tanto uma versão brasileira do enredo conspirativo mais típico do período entre a segunda metade do século XIX e os anos 1930 quanto do mais recente, posterior ao abrandamento do anti-semitismo.

\section{A "BLOGOSFERA"}

Como no exemplo francês de Mitterrand (Garrigou, 1992), a sucessão de escândalos que deveria conduzir à "desconstrução de Lula" não prevaleceu, demonstrando que não tivemos a multidimensionalidade das "verdadeiras" crises políticas conceituadas por Dobry (1986). Mais do que isso: a acusação de que a mídia e a oposição estariam conspirando contra a candidatura de Lula (Pereira, 18/10/2006) deflagrou a mobilização geral de seus partidários, até então constrangidos pela imposição das acusações ${ }^{13}$. No plano mais imediato, a seqüência de eventos mostra uma sucessão de golpes contra a postulação de Lula, seguida de uma resposta de seus partidários diferida, mas de magnitude inesperada, deflagrada a partir de um apoio praticamente marginal da mídia e da intensa ação no espaço da internet que essa contra-ação propiciou. Há mesmo quem diga que essa eleição assistiu ao nascimento de um novo contrapoder - a força da internet e da "blogosfera", contraposta a um, agora antigo, poder de monopólio da grande imprensa ${ }^{14}$.

Nosso caso empírico conforma-se assim a um padrão já conhecido, mas enriquecido pelo novo ingrediente. Voltando à História, na análise "pragmática" do escândalo, distingue-se esse evento do "caso". Essa diferenciação tem suas raízes na análise do affaire Dreyfus (Marrus, 1972; Blum, 1993; De Blic, 2005). Esse fenômeno social teve início como um escândalo: a acusação ao Capitão, seguida da condenação e do repúdio praticamente geral à sua conduta. No entanto, quando Zola lança seu "J'accuse", forma-se o campo dreyfusard e cria-se um "caso" no qual centenas de "pequenos intelectuais" espalhados por toda a França avocam a defesa pública para a inocência do condenado, que se realiza por meio de discursos e comícios, abaixo-assinados e toda a panóplia de técnicas de manifestação que então foram criadas. Segundo Charle (1990), esse momento marca o nascimento dos intelectuais en- 
quanto categoria social moderna ${ }^{15}$. Na análise do período que se inicia com a Revolução de 1848 e termina com a Primeira Guerra Mundial, Charle (2001) assinala a importância das transformações tecnológicas e organizacionais da vida intelectual daquele período para a conformação do novo personagem. É assim que, mutatis mutandis, as manifestações a que assistimos recentemente, que uns chamam de nova esfera pública da "blogosfera" e outros de "central de boatos petistas", parecem anunciar um fenômeno análogo (Sá, 2/11/2006; Veja, 18/10/2006; Nassif, 30/9/2006; Dimaggio et alii, 2001; LawsonBorders e Kirk, 2005; Sunstein, 2007).

Tradicionalmente, os boatos são manifestações anônimas, não registradas, que, quando podem ser referenciadas, servem de pista para o estudo das inquietações sociais e políticas da sociedade e do tempo (Lefebvre, 1988; Farge, 1992; Aldrin, 2005). O surgimento dos blogs, nos últimos anos, forneceu uma nova moldura para o espraiamento dos boatos. Dispondo dos blogs como novo suporte para sua difusão, agora os boatos podem ser mais facilmente referenciados e estudados em seu conteúdo e influência. De um lado a audiência dos blogs parece obedecer à hierarquia prévia da importância dos órgãos de comunicação, pois as páginas dos jornalistas identificados como seus porta-vozes recebem o maior número de visitas (Aldé, Escobar e Chagas, 2006). De outro, os posts - comentários e respostas dos responsáveis e dos leitores sobre o conteúdo dos blogs - que tais páginas recebem obrigam seus responsáveis a responder questões que não levariam em conta nos estados anteriores do debate público. É assim que, fenomenologicamente, o novo ambiente tecnológico produz novos constrangimentos institucionais e um evento que tinha a arquitetura de um "escândalo" acaba virando um "caso". Analiticamente, pode-se dizer que o novo contexto torna ainda mais mítica (no sentido antropológico) a idéia de conspiração. De um lado fica claro que, entre outros aspectos, estamos também diante de um novo contrapeso à propalada conspiração das elites (Sunstein, 2007); de outro, que a nova esfera de comunicação ajuda a propagar os rumores e as reações a eles, robustecendo a crença na conspiração e o "efeito de missa" que ela engendra.

Nesse exemplo recente, a capacidade organizacional do campo petista surpreendeu a muitos, e mais ainda o principal tema que esse grupo usou como mote da mobilização geral: o temor da sociedade contra um novo ciclo de privatizações. Em uma primeira análise, depois da "desconstrução de Lula", era inesperada a capacidade de reação dos gru- 


\section{Roberto Grün}

pos identificados com sua sigla, sobretudo porque ela se deu na esfera nova da internet, tida como um espaço de vanguarda, no qual os estratos intelectualmente dominantes deveriam reinar absolutos. Pensando paralelamente nas situações européias da segunda metade do século XIX que Charle (2001) descreve, é muito provável que estejamos vivendo algum tipo de subversão das hierarquias intelectuais. Se pensarmos a partir da noção de campo, veremos que a configuração que transparece nas eleições de 2006 não é surpreendente; é sociologicamente esperado que os grupos intelectualmente dominados estejam sempre procurando subverter as "regras do jogo" (Bourdieu, 1992). Quando surge uma nova tecnologia social de difusão de argumentos e, simultaneamente, como nos momentos eleitorais, aparece também a predisposição social para escutá-los, podemos esperar que as tentativas de inverter o jogo social apareçam com toda a intensidade. O próprio eixo da controvérsia pública, centrado na oposição "central de boatos petista" versus "emergência da blogosfera", revela a tensão entre grupos colocados em posições estruturalmente diferentes nos espaços intelectual e político: aqueles que incorporaram a primeira versão, no lado "conservador" e até então dominante; os outros, que aceitaram a versão da "blogosfera", no lado desafiante.

Em si mesma, a oposição sugere uma agenda e uma entrada interessantes para a sociologia da vida intelectual brasileira do início do século XXI e de suas relações com o espaço político. Dessa forma, configura-se uma hipótese contra-intuitiva baseada no argumento bourdieusiano: a energia social que explica o fenômeno deve ser buscada sobretudo na configuração do campo intelectual, e não no político (Bourdieu e Delsaut, 1975; Bourdieu, 1992). O Brasil das últimas décadas, especialmente depois do advento do presidente-intelectual Fernando Henrique Cardoso, vive uma configuração simbólica particularmente violenta, na qual os poderes dominantes naquela esfera coincidiram com os dominantes nas esferas política e econômica, não deixando nenhum espaço para a manobra dos dominados, que foram condenados ao ostracismo do "parque jurássico" (Grün, 2005b). Não é de espantar que, de repente, todos os descontentes com a ordem simbólica tradicional descarreguem sua insatisfação nos poderes intelectualmente estabelecidos. Nesse quadro, talvez o "petismo" e a grita contra a privatização devam ser entendidos mais como um suporte para a insatisfação difusa do que como uma pauta política coerente. Muito menos é inespera- 
da a reação dos "intelectuais tradicionais", deplorando a "boataria sem fundamento" e a "baixa densidade moral do povo brasileiro", que estaria se deixando levar pelo "prato de lentilhas" das esmolas governamentais, abandonando a direção moral e intelectualmente superior que até então controlava as formas de expressão legítimas da sociedade.

\section{A PRIVATIZAÇÃO COMO TEMA DE DEBATE E COMO CONSPURCAÇÃO}

O tema específico da privatização entra na agenda a partir da análise das reações dos eleitores à declaração de Alckmin de que venderia o novo avião da Presidência da República (O Globo Online, 8/10/2006; 9/10/2006). Ainda que o conhecido "latino-barômetro" assinalasse anualmente a impopularidade das privatizações, o tema parecia morto na doxa das elites (Shirley, 2005). Contudo, uma vez percebida a sensibilidade insuspeita, o jogo seguia implacável: para gáudio de uns e desalento de outros, descobriu-se que a população brasileira via nas privatizações medidas impopulares e as associava ao partido de Fernando Henrique Cardoso (Folha Online, 10/10/2006). Na linguagem indígena dos especialistas em marketing eleitoral, "o jacaré abre a boca". Após uma nítida ascensão de Alckmin, que culmina em sua votação surpreendentemente alta no primeiro turno, o vetor se inverte, pois as intenções de voto em Lula começam a crescer em um ritmo inesperado até então (O Estado de S. Paulo, 26/10/2006). Ao fim e ao cabo, ainda que os escândalos diretamente políticos tivessem mexido com a sensibilidade popular, o desfecho das eleições denota que a grande conspurcação foi o processo de privatização. Podemos assim enquadrar, por esse caminho indireto e tortuoso do (fracassado) scandalmaking, a pista heurística revelada nas eleições de 2006 na teoria durkheimiana do escândalo como revelador de normas sociais em vigor na sociedade; em nosso caso, pouco evidentes em virtude da barragem simbólica. Nesse quadro, fica assim fortemente sugerido que a validade da abordagem estratégica é mais situada do que imaginam os atores políticos e "conspiracionistas" de diversos matizes. A tecnologia social das pesquisas qualitativas, que sistematizam as pistas dadas pelos eleitores aos responsáveis políticos e publicitários das campanhas políticas, "deu o mote" para os grupos identificados com a campanha de Lula agir como os "pequenos intelectuais" do caso Dreyfus, mas agora dotados de novas ferramentas de comunicação e mobilização. Proverbialmente, eles não estavam mobilizados e preparados para o conjunto de eventos como conviria a um "exército político profissional", mas fo- 


\section{Roberto Grün}

ram coletivamente despertados pela ação de seus opositores "moralizantes". Afinal, como no desenho animado da Disney, o aprendiz de feiticeiro sabe invocar a mágica, mas não sabe dosá-la nem conjurá-la ${ }^{16}$.

Contrariando a doxa erudita, a maior parte da população brasileira faz um balanço negativo das privatizações das empresas de serviços públicos (Shirley, 2005). A doxa havia obliterado o tema do rol dos possíveis pontos de controvérsia na primeira fase do processo eleitoral. Afinal, todos "sabiam" que a privatização trouxera a universalização da telefonia celular e a melhoria das estradas estaduais paulistas e de algumas federais, ainda que o apagão de 2000 tivesse dificultado ligeiramente a crença (Grün, 2005a). No espaço do "debate público", as eventuais críticas que faziam menção ao aumento do peso das tarifas de serviços públicos nos orçamentos domésticos e comerciais eram vistas como jeremiadas dos derrotados ${ }^{17}$. Elas eram desqualificadas, expunham seus porta-vozes ao ridículo, e assim a expressão de qualquer ponto de vista discordante era desencorajada. No entanto, a evidência dificilmente descartável de uma eleição presidencial pôs a doxa em "suspeição". Quando a agudeza do embate diminuiu o espaço para o fairplay, nosso tool kit foi revirado mais profundamente e rompeu-se o consenso tácito sobre a adequação do processo de privatização. Dessa forma, a guerra cultural que estava represada encontrou na campanha eleitoral um caminho para voltar a se manifestar ${ }^{18}$.

\section{RESULTADO INESPERADO DA GUERRA CULTURAL}

À primeira vista é surpreendente que o mote das privatizações tivesse um efeito tão importante na disputa eleitoral. Isso acontece porque os resultados da guerra cultural que atravessa a sociedade brasileira dos últimos anos foram naturalizados; e porque seus vencedores provisórios foram alçados a porta-vozes do bom senso, e os derrotados lançados no oblívio social (Grün, 1999). Estamos diante de um caso típico de violência simbólica (Mauger, 2006). A sociedade aceita tanto o padrão de sociabilidade imposto pela dominação financeira quanto a valoração social produzida na contenda que esquecemos as lateralidades e disputas que engendraram a situação atual. Como na descoberta de uma inscrição arqueológica, a chacoalhada imprevista, causada pelas interações produzidas nas disputas simbólicas políticas e eleitorais, acabou fazendo "voar a areia" que recobria a apreciação social controversa de um fenômeno que críamos estar arquivado na história econômica e social do país. De um lado, evoé para as eleições por permitirem 
auscultar a sensibilidade popular; de outro, algumas perguntas: como é possível que se tenha estabelecido um consenso culto tão forte que bloqueou as evidências sobre o caráter controverso das privatizações? Como esse consenso evoluirá depois de abalado? Findo o período de agitação "plebéia" que corresponde às eleições, ele ainda pode ser restabelecido? Será que, uma vez tendo entrado na "caixa de ferramentas" culturais da sociedade, ele será utilizado novamente nas próximas contendas político-eleitorais (e com igual possibilidade de sucesso)?

O consenso culto deve ser considerado da perspectiva da guerra cultural, e não como um traço já "natural" da sociedade. Diversos episódios anteriores mostraram essa característica de noção que precisa ser constantemente refeita. Entre eles podemos lembrar o episódio da fracassada tentativa de mudar o nome da Petrobras para Petrobrax e a reação a essa medida que aparentemente prenunciava sua privatização ${ }^{19}$. Outro episódio é a construção do personagem público Daniel Dantas como o plutocrata tropical. A ereção desse totem moderno foi causada pelo mal-estar da sociedade em relação à ordem financeira em geral e ao processo de privatização em particular (Grün, 2007b). Nos dois casos, vemos transparecer que o problema das privatizações ainda não está resolvido; os esforços para criticá-las são ripostados com maior ou menor sucesso pelos partidários da doxa econômica. Nessa contenda ao mesmo tempo econômica e cultural, podemos observar diversos pontos de equilíbrio: a crítica "estatizante" à possível privatização da Petrobras foi capaz de interromper um processo de modernização da empresa que muitos consideravam ser o primeiro passo para privatizá-la ${ }^{20}$. Por outro lado, a crítica ao "apagão" do setor elétrico não foi capaz de reverter o processo nesse setor. Mesmo assim, podemos inferir que os diversos episódios mostravam a ausência de consenso social sobre o assunto, ainda que o senso comum culto apontasse o contrário. Também devemos notar que os casos isolados que indicavam o contencioso jamais chegaram a se alçar a uma crítica geral ao processo de privatizações, muito menos a uma crítica à condução geral da economia a partir dos parâmetros fixados pela ortodoxia "neoliberal".

A diferença entre os episódios citados e a agenda de temas eleitorais de 2006 é que, nesse último momento, a positividade das privatizações foi diretamente desafiada no espaço mais geral possível, e imediatamente a sirene tocou, indicando o perigo a que a ortodoxia estava sujeita. Não foi por acaso que os analistas identificados com a doxa econômica dominante passaram a fazer previsões sombrias a respeito do futuro da 
economia brasileira (Sardenberg, 2/11/2006; Lamucci, 24/10/2006). Reparemos que, na prática retórica dos economistas mainstreamers, há uma possibilidade de derivação "perversa" dessa constatação. Se o povo (e o governo) brasileiro continua acalentando esses sonhos "regressistas", emprestar dinheiro ao Brasil ou no Brasil continua sendo uma atividade de alto risco e, portanto, deve ser remunerada como tal. O ânimo antiprivatista demonstraria que os marcos legais que regem a sociedade brasileira não estão assegurados, e assim a chamada "tese jurisdicional" - que diz que os juros altos cobrados pelos bancos brasileiros são devidos à insegurança dos aplicadores - ganha mais verossimilhança. Logo, a forma como o assunto evoluiu no final de 2006 acaba se tornando mais um argumento para a manutenção dos juros altos que remuneram o mercado financeiro e penalizam os demais setores da sociedade.

No quadro anterior, um governo interessado em conseguir a boa vontade dos financistas para diminuir o custo do dinheiro tem pouco interesse econômico para estimular um novo debate sobre privatizações. No entanto, uma vez demonstrado que o tema desperta muita sensibilidade, há sempre o risco de ele ser acaparado por outros atores. Essa possibilidade torna o jogo simbólico menos previsível e menos diretamente dependente de disputas econômicas e políticas. Abre-se assim uma discussão sobre o alcance da temática. Ainda que seus resultados não sejam previsíveis, fica evidente seu papel indiciário como revelador de fissuras na doxa econômica e cultural.

Nesse ponto da análise, o jogo parece imprevisível, embora os atores que nele atuam mantenham a crença tanto em sua previsibilidade quanto na possibilidade de controlá-lo segundo seus propósitos e interesses e/ou, pelo contrário, na ameaça de que seus adversários o façam. Podemos então falar em uma concepção "judô" de vida social e política, vista como uma seqüência de golpes e contragolpes, na qual a melhor conduta é antecipar-se aos golpes imputados aos adversários. Essa tendência se inscreve em um vetor mais geral: um dos traços da modernidade é justamente a tentativa de "controle do acaso" (Hacking, 1990; Desrosières, 1993), e um conjunto grande de técnicas político-eleitorais e financeiras foram desenvolvidas para essa finalidade (Porter, 1995). Podemos assim imaginar que os mecanismos de ataque e de defesa diante desse fenômeno fazem parte dessa mesma tendência de tentar "normalizar" as interações sociais. É assim que, como em uma atividade de estado maior militar, uma campanha eleitoral bem 
planejada deve preparar com antecedência seu arsenal de táticas de ataque e de defesa diante dos adversários, explorando as fraquezas imputadas aos últimos e preparando justificativas e contra-ataques para fazer frente à exploração das fraquezas de suas posições (Jamieson, 2000). Como no exemplo do dossiê-gate, dado que esse conjunto de atividades tem se tornado previsível e burocratizado, é bem provável que com o tempo as táticas percam sua eficácia simbólica direta ${ }^{21}$, cumprindo cada vez mais o papel involuntário de "levantar a poeira" que recobre conteúdos simbólicos ignorados do que efetivamente produzindo os efeitos esperados por seus operadores (Garrigou, 1992). Analiticamente, esse resultado pode ser assimilado ao conjunto de técnicas financeiras, originalmente concebidas para controlar o risco de prejuízo de investidores, cuja disseminação cria, ela mesma, novos riscos para os indivíduos e instituições que as aplicam (Mackenzie, 2001; Mackenzie e Millo, 2003; Shiller, 2003). Como no caso das finanças, sua implementação, ainda que não seja eficiente para as finalidades propostas, produz dois efeitos relevantes: neutralizar ou passar por cima de conteúdos morais que anteriormente impediam a propagação de condutas duvidosas ou arriscadas para seus praticantes e a sociedade; e, a exemplo do mercado financeiro de futuros, produzir novas zonas de incerteza. Dessa maneira, a descoberta e a produção de conteúdos morais que alteram a estrutura simbólica da sociedade são curiosos efeitos colaterais da disputa política.

\section{DO "JORNALÍSTICO" AO "SOCIOLÓGICO"}

Nossos escândalos, que em um primeiro momento pareciam tsunamis, não teriam então passado de simples marolas? A essa altura da análise, fica claro que essa analogia, ainda que tentadora, é pobre. Ela deixa de lado tanto seus efeitos colaterais, que são muito importantes, quanto sua quase inevitabilidade, que é engendrada pela concorrência social interna e multidimensional nos diversos segmentos do campo do poder. Na medida em que os escândalos alteram a estrutura simbólica da sociedade, produzem efeitos interessantes e provocam a sociologia a dar conta de sua gênese, estrutura e efeitos. Contudo, muito além das intenções de seus deflagradores, eles se desenvolvem em uma dinâmica incontrolável.

Há uma lógica na dinâmica simbólica que pode ser identificada nas oscilações (provisoriamente chamadas de) pendulares que regem o debate econômico brasileiro e que, muito provavelmente, podem expli- 


\section{Roberto Grün}

car configurações mais gerais da sociedade. Privatização de empresas e serviços públicos são eventos considerados positivos em um enquadramento cognitivo cuja suprema idéia positiva é a de "livre organização" e seus corolários econômicos, como o de mercado, livre concorrência e "Estado mínimo" (Guex, 2003). A promessa essencial dessa forma de argumentar é a abundância tanto de produtos quanto de oportunidades econômicas. Para que essa seqüência mnemônica funcione bem, é necessário um aumento na oferta de produtos novos e daqueles que antes eram difíceis, que também devem ser considerados baratos $^{22}$. Só assim essa idéia mantém na latência a noção rival de hierarquia, que tem como característica central o conceito de "Estado regulador", que planeja a economia prometendo garantir os mínimos sociais e preservar a coesão social, mas sem necessariamente dar conta da evolução tecnológica e econômica (Lakoff, 1996; 2004; Douglas e Ney, 1998).

Podemos ver manifestações da tensão simbólica (e social) em diversas arenas específicas, como na noção mais geral de empresa e de organização (Grün, 1999; 2004b); na disputa sobre a forma "correta" de organizar a previdência social (idem, 2003; 2005b); ou na forma de discutir as razões e soluções para a crise de energia que se abateu sobre o Brasil no início do século XXI (idem, 2005a). Nesse quadro de referências, os escândalos e a reação a eles, culminando com as eleições de 2006, teriam produzido um conjunto de descargas de energia social suficiente para mover o pêndulo cultural? O evento é inédito? É inédita a apreciação que está recebendo? O que essa configuração denota a respeito do conflito simbólico mais geral?

Um olhar apressado diria: sim, o pêndulo está mexendo celeremente no sentido contrário ao da doxa econômica; porém, já tivemos momentos anteriores nos quais esse movimento parecia estar se produzindo. Entretanto, ou ele não ocorreu, ou foi abortado. Além dos exemplos pontuais do segundo mandato de Fernando Henrique Cardoso já lembrados, um dos mais expressivos foi o momento imediatamente posterior à posse de Lula em 2002. Durante o processo eleitoral que culminou com aquela primeira vitória do candidato do PT, o ambiente ficou saturado com as ameaças de "argentinização" do Brasil: a ameaça, parcialmente concretizada, de uma corrida contra o Real que tornaria impossível a administração do país por Lula, a exemplo do que acabava de acontecer com a presidência de De la Rúa no país vizinho. No entanto, mesmo nesse contexto, em que a espada de Dâmocles dos mercados 
financeiros internacionais pairava sobre a cabeça do candidato, ele acabou sendo eleito por expressiva maioria.

Recém-eleito e empossado, o primeiro governo Lula lançou a iniciativa legislativa da emenda que regulamentaria o art. 192 da Constituição de 1998. Seus pontos, que conduziriam à mudança de algumas regras do sistema financeiro, foram fulminados por uma saraivada de críticas ortodoxas, sem uma defesa correspondente daqueles que poderiam opor-se a elas. Essa configuração, que se mostrou muito pouco favorável ao questionamento da ortodoxia, retraiu qualquer possibilidade de avanço na criação de alguma descontinuidade marcada no que tange à condução da economia empreendida pelo governo anterior (Barbosa e Villalba, 30/3/2003; Leonel e Leonel, 26/3/2003; Grün, 2007a). Ainda que aquele governo tenha implementado diversas mudanças em relação à condução anterior da economia, como a difusão do microcrédito e do crédito consignado, e resistido à pressão para tornar o Banco Central legalmente autônomo, dificilmente alguém sustentaria que o pêndulo tivesse efetivamente mudado de direção (Grün, 2004a). Bem ao contrário, no espírito de Shiller (2003), poderíamos falar que se tratou de uma maior extensão do "paradigma financeiro" para incluir em seu halo diversos setores sociais e econômicos antes excluídos das facilidades concedidas pelos mercados.

Por outro lado, também é relevante assinalar que o "paradigma financeiro" comporta variações relevantes. A financeirização que a sociedade brasileira está experimentando na última quadra tem peculiaridades importantes, que vão mesmo além da inclusão de setores populares em sua lógica. Elas também afetam o espaço dos mercados de maneira mais geral. Talvez o exemplo mais interessante que concorre para a afirmação dessa diferença específica seja o desenvolvimento recente dos fundos de private equities. Internacionalmente, o uso intensivo dessa ferramenta financeira, a partir do início do século XXI, tem sido apontado como uma verdadeira nova fase do capitalismo (Welch e Welch, 9/7/2007; The Economist, 25/11/2004; Dougherty e Werdigier, 29/6/2007). Depois dos "excessos" regulatórios associados à Lei Sarbanes-Oxley, as private equities surgem como uma forma de restaurar o dinamismo do universo empresarial. Nesse quadro, a idéia de governança corporativa, antes considerada uma das principais características positivas do mercado financeiro norte-americano, torna-se uma propriedade negativa que impede o desenvolvimento dos negócios. Não sem surpresas, o novo desenvolvimento atrai rapidamente críti- 


\section{Roberto Grün}

cas dos setores que se sentem incomodados pela expansão das finanças e se concretiza nas tentativas de aumentar a taxação da "indústria" nos vaticínios de que o instrumento aumentaria a instabilidade das economias nacional e internacional, além de ser um instrumento de concentração de riquezas implicitamente injusto (Conway, 6/7/2007; Sorkin e Dash, 8/1/2007; The Economist, 8/2/2007; Boucher, 17/6/2007; Anderson e Sorkin, 23/6/2007; Smith, 26/1/2007). Nas primeiras apreciações da sociologia econômica, as private equities passam a ser apontadas como o exemplo mais acabado da predominância financeira e dos constrangimentos que ela produz sobre as sociedades contemporâneas (Froud e Williams, 2007).

No Brasil, essa ferramenta aportou durante o período de privatização das estatais e, analogamente ao que se passou nos mercados centrais, esteve associada às articulações de Daniel Dantas, nas quais os fundos de pensão foram obrigados a desempenhar um papel passivo (Santos, 18/6/2007; Senado, 21/9/2005; Grün, 2007b). Logo, dificilmente seria bem aceita pelo grupo que chegou ao poder com Lula. A mágica das interações sociais, porém, acaba produzindo um híbrido muito interessante. Depois de um período inicial de repulsa, os fundos de pensão passam a aceitar o instrumento, o qual, na mão de financistas como Armínio Fraga e Antonio Kandir, menos estigmatizados do que Dantas, também ganha outro sentido, incorporando, pelo menos retoricamente, a idéia de governança corporativa cara aos sindicalistas e administradores dos fundos de pensão. Vemos assim desfilar diante de nossos olhos uma interessante cronologia, na qual o ambiente peculiar do Brasil governado por Lula vai alterando o sentido internacional das private equities, infundindo-lhes características que as tornam palatáveis àqueles que desejam uma situação de compromisso entre o mundo das finanças e os demais setores da sociedade, em um sentido contrário ao que a ferramenta financeira tem adquirido na cena internacional (Santos, 1ㅇ/6/2007; Camba, 3/9/2003; Gazeta Mercantil, 3/5/2004; Camba e Fortunato, 8/8/2003; Cançado e Grinbaum, 15/1/2007; Santos, 18/6/2007; Martins, 27 /4/2006). A tendência já se descortinava no final do primeiro período de Lula, mas ela ganha muita intensidade no início de 2007, quando passa a ser um instrumento para captação e concentração de recursos para aplicação no frenético mercado de combustíveis vegetais renováveis (Gaspar, 3/5/2007; Palhano, 16/4/2007; Carvalho, 24/8/2006).

O dossiê reaberto da privatização revelou publicamente o espaço que há para investidas retóricas na direção do questionamento da doxa 
econômica. Como vimos, é da lógica da dinâmica social, em geral, e da competição política, em particular, que esse tema seja apropriado e utilizado por alguns dos agentes engajados nesse espaço. Isso basta para fazer mover nosso pêndulo para o lado do planejamento? Vimos diversas manifestações culturais que denotam contrariedade ao predomínio da "razão financeira" no Brasil recente. Nenhuma delas, entretanto, alcança um grau suficiente de generalidade para transcender o estágio de crítica pontual, que aponta simplesmente para a necessidade de aperfeiçoamento das ordens econômica e social baseadas nas finanças. Os exemplos do microcrédito e do crédito consignado são mostras do que Boltanski e Chiapello (1999) chamam de críticas "recuperáveis" e, por isso, funcionais à ordem financeira, uma vez que contribuem para torná-la mais legítima. Os autores também lembram que a inclusão da crítica transforma o próprio capitalismo. O desenvolvimento da governança corporativa no Brasil, que se tornou um verdadeiro cavalo de batalha para os sindicalistas transformados em gestionários dos fundos de pensão, já demonstrava essa tendência (Jardim, 2007). A "tropicalização" subseqüente dos fundos de private equities é mais uma evidência que chama a atenção para essa forma peculiar de capitalismo contemporâneo que vemos se desenvolver no Brasil atual.

Os escândalos parecem mostrar a resistência às novidades; compreensível, pois elas desarrumam o campo do poder, questionando a hierarquia estabelecida entre as elites econômicas e também entre as políticas e intelectuais. Afinal, o que é melhor para o capitalismo em geral ou para a ordem financeira em especial não o é, necessariamente, para os capitalistas e financistas já existentes em particular. Nem os movimentos culturais que dão maior estabilidade à ordem simbólica são necessariamente reconhecidos positivamente por aqueles que manipulam a simbologia tradicional; daí ser razoável prever que viveremos no futuro diversos sobressaltos escandalizantes. Neles serão testadas tanto a força da doxa econômica quanto a das idéias e atores cuja sobrevivência no tabuleiro depende de mudanças na arquitetura tradicional. De definido, apenas o movimento, mas ele nos lembra não só que o futuro está aberto e que depende das lutas do presente como também do caráter eminentemente cultural das disputas.

(Recebido para publicação em janeiro de 2007) (Versão definitiva em fevereiro de 2008) 


\section{Roberto Grün}

\section{NOTAS}

1. O caso Waldomiro iniciou-se em $12 / 2 / 2004$, com a revelação de um vídeo, gravado em 2002, no qual Waldomiro Diniz, então subchefe de Assuntos Parlamentares da Presidência da República, é filmado pedindo contribuições para as campanhas de Benedita da Silva e Rosinha Mateus para o governo estadual do Rio de Janeiro, além de pedir propinas para si mesmo (Meireles e Krieger, 16/2/2004). Seguiram-se sua exoneração e o início de um conjunto de acusações contra o governo federal daquele momento.

2. O mensalão foi um episódio que começou com a apresentação, em rede nacional, de um tape mostrando um alto funcionário da Empresa Brasileira de Correios e Telégrafos, Maurício Marinho, recebendo uma soma de dinheiro líquido que teria sido a contrapartida a uma ajuda irregular que ele teria fornecido a "Carlinhos Cachoeira", um empresário que tinha um contrato relacionado à operação de loterias federais. Nesse "flagrante", o nome do deputado Roberto Jefferson, então presidente do Partido Trabalhista Brasileiro - PTB, foi citado como protetor de Marinho, e o ato foi considerado uma traição do governo federal ao grupo liderado por Jefferson. Este retaliou denunciando a existência de um "mensalão": pagamento de mensalidades a deputados pertencentes a partidos da base de sustentação do governo de Luiz Inácio Lula da Silva em troca de apoio ao governo em votações e demais atividades parlamentares (Prete, 6/6/2005; Dines, 10/4/2006; Recondo e Silveira, 15/6/2005; Sternhell, 1997). As ondas de choque produzidas pela seqüência fizeram surgir a Comissão Parlamentar Mista de Inquérito dos Correios em 2005-2006, cujas atas e tapes estão disponíveis no site do Senado Federal brasileiro (Dines, 10/4/2006; Senado, $21 / 9 / 2005)$.

3. O dossiê-gate foi a acusação de que integrantes da campanha do presidente Lula à reeleição teriam tentado comprar um dossiê que incriminaria José Serra, então principal candidato ao governo do Estado de São Paulo pela oposição ao governo federal. Esse dossiê conteria dados comprometedores, que revelariam a participação de Serra em esquemas de corrupção na compra de ambulâncias por parte do Ministério da Saúde durante sua gestão dessa pasta no governo Fernando Henrique Cardoso. Houve uma apreensão, em um flagrante policial controvertido, de um montante de dinheiro líquido que seria utilizado para o pagamento dessa peça de acusação, amplamente divulgado pela imprensa (Menezes et alii, 18/9/2006; Guerreiro, 19/9/2006). Por sua vez, a "grande imprensa" foi acusada de ter preferido essa pauta à de um grave acidente aéreo ocorrido na mesma data, porque pretendia prejudicar a candidatura de Lula à reeleição (Pereira, 18/10/2006).

4. Creio que a série de reportagens sobre as mordomias do setor estatal, iniciada em 1976 (Kotcho, 1ㅇ / / 1976; 2005), deflagra um conjunto de mudanças simbólicas favoráveis ao predomínio recente das finanças na sociedade brasileira. Uma cronologia para essas mudanças é proposta em Grün (1999).

5. Na Grã-Bretanha, a temática sexual está presente desde o período vitoriano, como mostra Thompson (2000).

6. Codificada e operacionalizada, a "sabedoria" do ataque à conduta pessoal dos políticos e demais homens públicos pode ser buscada e entendida em Luntz (1988; 2007). Também pode ser compreendida como técnica retórica mais geral em Jamieson 
(1992); e as lógicas mnemônicas que ela deflagra podem ser entendidas a partir de Lakoff (2004).

7. Isso revela uma dinâmica social muito parecida com aquela descrita para seu equivalente francês, que começa a se impor algum tempo antes (Adut, 2004).

8. Ver http://en.wikipedia.org/wiki/lewinsky_scandal. Acessado em 6/10/2006.

9. Segundo consta do jornal O Estado de S. Paulo (11/4/2005), o livro vendeu 750 mil cópias no Brasil entre meados de 2004 e 2005, seu primeiro ano de circulação.

10. Ver, entre outros, o site http://senhoresdomundo.blogspot.com. Acessado em $30 / 6 / 2006$.

11. No posfácio a Fleck (1979) [1935], Thomas Kuhn assinala que a famosa noção de "paradigma científico" pode ser inscrita na linhagem da sociologia da ciência durkheimiana como evolução do conceito de "família de pensamento" cunhado por Fleck.

12. Inversamente, quando a concorrência multidimensional no campo do poder leva a uma agenda ou interpretação que lhes é favorável, o resultado é atribuído à razão, à natureza, a alguma força sobrenatural e ao fracasso dos conspiradores.

13. Fenômeno que a comunicação política chama de "efeito backlash". Curiosamente, ele não foi previsto, ao menos publicamente, pelos especialistas locais do marketing político, ainda que sua descrição estivesse disponível nos manuais didáticos, como o de Jamieson (2000).

14. Ver o blog do jornalista Luis Nassif no site http:/ / z001.ig.com.br/ig/04/39/946471/ blig/luisnassif, acessado em 1으11/2006. Ver ainda comentários no mainstream jornalístico reconhecendo o interesse pelo assunto levantado em http://todamidia. folha.blog.uol.com.br. Acessado em 1으11/2006.

15. O novo grupo constituiu-se a partir de uma lógica de funcionamento interno e de uma economia política estruturalmente diferente dos "Philosophes" - grupos de aristocratas e burgueses que, como nos mostra (Chartier, 2000), prepararam culturalmente a Revolução Francesa. Seus ancestrais mais diretos podem ser encontrados na bohème litteraire descrita por Darnton (1982).

16. Ainda que o principal publicitário da campanha de Lula tenha assinalado que o material sobre o tema privatização já estivesse preparado anteriormente, segundo Rodrigues $(5 / 11 / 2006)$, "esse é um tema riquíssimo que foi muito bem pensado. Nós tínhamos alinhado alguns dos temas de intensa fragilidade e de imensa comoção política. Estava em primeiro lugar a privatização. Não usamos no primeiro turno porque não houve necessidade de embate direto". Não é surpreendente que Schudson (1984), nesse espaço que se quer altamente profissionalizado, mas no qual a personalização dos feitos é a regra, avoque a si um feito "estratégico", ainda que as evidências apontem ter sido o resultado de interações sociais bem mais amplas do que desígnios pessoais. Proverbialmente, o entrevistador o cobra diversas vezes, e ele dá seguidas mostras de concordar com a doxa culta sobre a privatização como um benefício à sociedade. De qualquer forma, vale reproduzir Schudson (1995:22): “Os consultores políticos, sempre se dizendo experts, dão conselhos conflitantes e alteram seus conselhos de uma eleição para outra. [Como quer Bob Goodman,] Nós ainda somos artistas tentando descobrir um jeito de chamar a atenção [do eleitorado] e encontrar soluções... Mas nós não sabemos grande coisa. E se soubéssemos, seríamos realmente perigosos". 


\section{Roberto Grün}

17. Ainda que as evidências nesse sentido fossem fortes e persistentes, como nos mostram os índices de preços, inclusive os mais recentes (Banco Central do Brasil, 2006).

18. Utilizo aqui o termo "guerra cultural" em um sentido ligeiramente diferente daquele empregado pelos norte-americanos (Hunter, 1991; Williams, 1997; Rieder e Steinlight, 2003). Na versão original norte-americana, trata-se de um recurso analítico para dar conta da possível oposição crescente entre pontos de vista conservadores e liberais sobre os mais diversos assuntos econômicos e sociais ali discutidos. Aqui, tento adaptar o conceito a partir de uma leitura inspirada em Bourdieu (1997). Trata-se então de lembrar que a discussão sobre as possibilidades econômicas abertas à sociedade brasileira depende dos enquadramentos culturais que balizam as possibilidades cognitivas e retóricas dos atores. Conseqüentemente, o essencial da disputa política se dá em torno das flexões culturais (Grün, 1999).

19. Ainda que, em 6 de novembro de 2006, Fernando Henrique Cardoso afirmasse peremptoriamente que não era esse o objetivo, a conjuntura da época sugere fortemente essa hipótese (Teodoro, 6/11/2006; Oliveira, 2000; Grün, 2005a).

20. O cerne organizacional da proposta era a divisão da empresa em "unidades de negócio" independentes. Essa medida foi também o primeiro passo para a privatização do setor elétrico paulista e foi repetida muitas vezes nas "receitas de privatização" oferecidas pelos órgãos financeiros multilaterais e pelas empresas de consultoria (Carter e Mueller, 2006). Logo, era alta a verossimilhança da crítica que dizia ser a adoção das "unidades de negócio" um importante passo preliminar da privatização.

21. Possivelmente porque faltaria aos "estados-maiores" das campanhas políticas o capital simbólico que é próprio dos verdadeiros empreendedores morais.

22. Essa vertente também dá ênfase à noção mais geral de liberdade individual (Douglas, 1996). O mesmo desdobramento mnemônico deveria então levar a uma maior abertura em termos de direitos reprodutivos e questões de gênero, como as uniões entre homossexuais, mas pouca sensibilidade para questões de multiculturalismo, como a das cotas para estudantes afrodescendentes nas universidades públicas. Notavelmente, o "neoliberalismo" brasileiro mostrou as amarras que o prendem ao tradicionalismo quando não deu ênfase às questões de gênero, mesmo tendo membros importantes da intelligentsia nacional em postos-chave do governo federal. 


\section{REFERÊNCIAS BIBLIOGRÁFICAS}

ADUT, Ari. (2004), "Scandal as Norm Entrepreneurship Strategy: Corruption and the French Investigating Magistrates". Theory and Society, vol. 33, pp. 529-578.

ALDÉ, Alessandra, ESCOBAR, Juliana e CHAGAS, Viktor. (2006), “A Febre dos Blogs de Política". Anais do XV Encontro Anual da Compós, Bauru, vol. 1.

ALDRIN, Philippe. (2005), Sociologie Politique des Rumeurs. Paris, PUF, vol. 1.

ANDERSON, Jenny e SORKIN, Andrew Ross. (2007), "Bill Is Offered to Increase Tax on Private Equity". The New York Times, 23 de junho.

BANCO CENTRAL DO BRASIL. (2006), Índices de Preços. Atualizado em agosto de 2006, com dados até junho de 2006.

BARBOSA, Marina e VILLALBA, Patrícia. (2003), "Radicais do PT Insistem em Adiar Votação". O Estado de S. Paulo, 30 de março.

BECKER, Howard S. (1963), Outsiders. Studies in the Sociology of Deviance. London, Free Press of Glencoe.

BLAIR, Margaret M. (2003a), "Reforming Corporate Governance: What History Can Teach Us". Research Paper, no 485.663, Georgetown University Law Center.

. (2003b), "Shareholder Value, Corporate Governance and Corporate Performance: A Post-Enron Reassessment of the Conventional Wisdom", in P. K. Cornelius e B. Kogut (eds.), Corporate Governance and Capital Flows in a Global Economy. Oxford, Oxford University Press.

BLUM, Léon. (1993), Souvenirs sur l'Affaire. Paris, Gallimard.

BOHN, C. (2006), “La Societé Mondiale. Les Concepts de Société Opératoires dans les Théories Sociales de Bourdieu et de Luhmann", in H.-P. Müller e Y. Sintomer (eds.), Pierre Bourdieu, Théorie et Pratique: Perspectives Franco-Allemandes. Paris, La Découverte, pp. 101-124.

BOLTANSKI, Luc e CHIAPELLO, Eve. (1999), Le Nouvel Esprit du Capitalisme. Paris, Gallimard.

BOLTANSKI, Luc, DARRÉ, Yann e SCHILTZ, Marie-Ange. (1984), “La Dénonciation”. Actes de La Recherche en Sciences Sociales, no 51, pp. 3-40.

BOUCHER, Eric Le. (2007), "La Société Agressive par Actions". Le Monde, 17 de junho. BOURDIEU, Pierre. (1958), Sociologie de l'Algérie. Paris, PUF.

. (1974), "Avenir de Classe et Causalité du Probable". Revue Française de Sociologie, vol. 15 , no 1 , pp. 3-42.

. (1979), La Distinction: Critique Sociale du Jugement. Paris, Minuit.

(1980), Le Sens Pratique. Paris, Minuit.

. (1981), “La Représentation Politique: Eléments pour une Théorie du Champ Politique". Actes de la Recherche en Sciences Sociales, nos 36-37, pp. 3-24.

(1984), Homo Academicus. Paris, Minuit.

(1989), La Noblesse d'État: Grandes Écoles et Esprit de Corps. Paris, Minuit. 


\section{Roberto Grün}

_. (1992), Les Règles de l'Art: Genèse et Structure du Champ Littéraire. Paris, Seuil.

. (1997), Méditations Pascaliennes. Paris, Seuil.

e DELSAUT, Yvette. (1975), "Le Couturier et sa Griffe: Contribution à une Théorie de la Magie". Actes de la Recherche en Sciences Sociales, vol. 1, no 1, pp. 7-36.

BROWN, Dan. (2004), O Código Da Vinci. Rio de Janeiro, Sextante.

CAMBA, Daniele. (2003), “Nova Regra para Private Equity Gera Polêmica”. Valor Econômico, 3 de setembro.

e FORTUNATO, Patrícia. (2003), “Fundos de Pensão Divergem sobre Investimento em Private Equity". Valor Econômico, 8 de agosto.

CANÇADO, Patrícia e GRINBAUM, Ricardo. (2007), "Investidores Financeiros São a Nova Cara do Capitalismo no Brasil: Aplicações de Fundos em Empresas Emergentes Chega a R\$1 bilhão e Muda o Ambiente de Negócios no País". O Estado de S. Paulo, 15 de janeiro.

CARTER, Chris e MUELLER, Frank. (2006), "The Colonisation of Strategy: Financialisation in a Post-Privatisation Context". Critical Perspectives on Accounting, vol. 17, no 8, pp. 967-985.

CARVALHO, Denise. (2006), "Vai um Dinheiro Aí? Chega ao Brasil uma Nova Geração de Fundos Private Equity. E Ela Traz Consigo 2 Bilhões de Dólares para Investir". Exame, no 875, 24 de agosto.

CHAGAS, Helena. (2005), "Briga Empresarial Ajudou a Pôr Dirceu e Gushiken em Campos Opostos". O Globo, 31 de julho.

CHAMPAGNE, Patrick. (1984), “La Manifestation: La Production de l’Événement Politique". Actes de la Recherche en Sciences Sociales, nos 52-53, pp. 18-41.

(1990), Faire l'Opinion: Le Nouveau Jeu Politique. Paris, Minuit.

(1996), “Le Journaliste, Acteur de Société". Les Cahiers du Journalisme, no 2, Centre de Recherche de l'École Supérieure de Journalisme de Lille.

CHAMPAGNE, Patrick e MARCHETTI, Dominique. (1994), “L'Information Médicale sous Contrainte: A Propos du 'Scandale du Sang Contaminé'”. Actes de la Rechercheen Sciences Sociales, nos 101-102, pp. 40-62.

CHANTAL, François V. de. (2001), “Moralité Privée, Morale Publique. L’Exception Américaine", in J.-L. Briquet e P. Garraud (eds.), Juger la Politique: Entreprises et Entrepreneurs Critiques de la Politique. Rennes, Presses Universitaires de Rennes, pp. 287-301.

CHARLE, Christophe. (1990), Naissance des "Intellectuels": 1880-1900. Paris, Minuit. . (2001), Les Intellectuels en Europe au XIXe Siècle: Essai d'Histoire Comparée. Paris, Seuil.

CHARTIER, Roger. (2000), Les Origines Culturelles de la Révolution Française. Paris, Seuil.

COFFEE, John C. (2002), “Understanding Enron: It's About the Gatekeepers, Stupid”. Working Paper, no 207, The Center for Law and Economic Studies.

COHN, Norman. (1967), Warrant for Genocide: The Myth of the Jewish World Conspiracy and the Protocols of the Elders of Zion. New York, Harper \& Row. 
COLLINS, Randall. (2004), Interaction Ritual Chains. Princeton, Princeton University Press.

CONWAY, Edmund. (2007), "Darling Won't Clamp Down on Private Equity Tax". Telegraph, 6 de julho.

COSTA, Luciano Martins. (2005), "A Inexorável Desconstrução de Lula". Observatório de Imprensa, 25 de julho.

DARNTON, Robert. (1982), The Literary Underground of the Old Regime. Cambridge, Harvard University Press.

DE BLIC, Damien. (2003), Le Scandale Financier. Naissance et Declin d'une Forme Politique, de Panama au Crédit Lyonnais. Tese de doutorado em Sociologia, L'École des Hautes Études en Sciences Sociales, Paris.

_ . (2005), "Le Scandale comme Épreuve: Éléments de Sociologie Pragmatique". Politix, vol. 18, no 71, pp. 9-38.

DE GOEDE, Marieke. (2004), "Repoliticizing Financial Risk". Economy and Society, vol. 33, no 2, pp. 197-217.

. (2005), Virtue, Fortune, and Faith: A Genealogy of Finance. Minneapolis, University of Minnesota Press.

DESROSIÈRES, Alain. (1993), La Politique des Grands Nombres: Histoire de la Raison Statistique. Paris, La Découverte.

DIMAGGIO, Paul et alii. (2001), "Social Implications of the Internet". Annual Review of Sociology, vol. 27, no 1, pp. 307-336.

DINES, Alberto. (2006), "Rescaldo dos Escândalos: Em Defesa da Opinião Pública". Observatório da Imprensa, 10 de abril.

DOBRY, Michel. (1986), Sociologie des Crises Politiques: La Dynamique des Mobilisations Multisectorielles. Paris, Presses de la Fondation Nationale des Sciences Politiques.

DOUGHERTY, Carter e WERDIGIER, Julia. (2007), “Attracting Private Equity Becomes a National Sport in Europe". The New York Times, 29 de junho.

DOUGLAS, Mary. (1986), How Institutions Think. Syracuse, Syracuse University Press. (1996), Thought Styles: Critical Essays on Good Taste. London, Sage.

e NEY, Steven. (1998), Missing Persons: A Critique of the Personhood in the Social Sciences. Berkeley/London, University of California Press/Sage.

DUBY, Georges. (1978), Les Trois Ordres ou L'Imaginaire du Féodalisme. Paris, Gallimard.

ERNER, Guillaume. (2005), Expliquer l'Antisémitisme: Le Bouc Émissaire. Autopsie d'un Modèle Explicatif. Paris, PUF (prefácio de Pierre-André Taguieff).

FARGE, Arlette. (1992), Dire et Mal Dire: L'Opinion Publique au XVIII Siècle. Paris, Seuil.

FLECK, Ludwik. (1979) [1935], Genesis and Development of a Scientific Fact. Chicago, University of Chicago Press (edição de Thaddeus J. Trenn e Robert K. Merton e tradução de Fred Bradley e Thaddeus J. Trenn). 


\section{Roberto Grün}

FOLHA ONLINE. (2006), "Coordenador de Alckmin Acusa Lula de Espalhar Boatos; Lula Alerta para Privatizações". Disponível em http:/ / www1.folha.uol.com.br/folha/ brasil/ult96u85010.shtml, 10 de outubro.

(2006), "Jefferson Diz que Foi Procurado por Dantas para Denunciar PT". Disponível em http://www1.folha.uol.com.br/folha/brasil/ult96u79056.shtml, 30 de maio.

FROUD, Julie e WILLIAMS, Karel. (2007), "Private Equity and the Culture of Value Extraction". Working Paper, no 31, The University of Manchester.

GARRIGOU, Alain. (1992), “Le Président à l’Épreuve de le Scandale. Désestabilisation Apparente et Consolidation Fonctionelle", in B. Lacroix e J. Lagroye (eds.), Le Président de la République: Usages et Genèses d'une Institution. Paris, FNSP.

. (1993), "Le Scandale Politique comme Mobilisation", in F. Chazel (ed.), Action Collective et Mouvements Sociaux. Paris, PUF, pp. 183-191.

GASPAR, Malu. (2007), “As Empresas de Armínio: Ao Tornar-se Sócio do McDonald's, Ex-Presidente do BC Reforça sua Nova Estratégia de Investimentos". Exame, 3 de maio. Disponível em http://portalexame.abril.com.br/revista/exame/edicoes/ 0892/negocios/m0127995.html, acessado em maio de 2007.

GATES, Megan N. (2003), “The Sarbanes-Oxley Act and Non-US Issuers: Considerations for International Companies". Journal of Commercial Biotechnology, vol. 10, no 1, pp. 40-53.

GAZETA MERCANTIL. (2004), “Private Equity Terá Nova Regra no Brasil”, 3 de maio.

GIRARDET, Raoul. (1986), Mythes et Mythologies Politiques. Paris, Seuil.

GOIS, Chico de, JUNGBLUT, Cristiane e DAMÉ, Luiza. (2007), “Lula Sanciona Lei do Saneamento e Abre Caminho para Investimentos: Ao Aprovar o Marco Regulatório do Setor, Presidente Faz Críticas à Privatização". O Globo, 6 de janeiro.

GOODY, Jack. (1997), Representations and Contradictions. Ambivalence Towards Images, Theatre, Fiction, Relics, and Sexuality. Cambridge, Blackwell.

GRÜN, Roberto. (1999), "Modelos de Empresa, Modelos de Mundo: Sobre Algumas Características Culturais da Nova Ordem Econômica e da Resistência a Ela". Revista Brasileira de Ciências Sociais, vol. 14, no 41, pp. 121-140.

. (2003), "Fundos de Pensão no Brasil do Final do Século XX: Guerra Cultural, Modelos de Capitalismo e os Destinos das Classes Médias". Mana, vol. 9, no 2, pp. 7-38.

. (2004a), “A Evolução Recente do Espaço Financeiro no Brasil e Alguns Reflexos na Cena Política". DADOS, vol. 47, no 1, pp. 5-47.

. (2004b), “O ‘MBA' como um Brevê de Internacionalização e de Contemporaneidade Profissional entre Engenheiros", in A. M. F. Almeida et alii (orgs.), Circulação Internacional e Formação Intelectual das Elites Brasileiras. Campinas, Unicamp, pp. 282-298.

. (2005a), “Apagão Cognitivo: A Crise Energética e sua Sociologia". DADOS, vol. 48, no 4, pp. 891-928.

. (2005b), “O ‘Nó' dos Fundos de Pensão e os Dilemas da Sociedade Brasileira”. No-

vos Estudos Cebrap, vol. 73, pp. 19-31. 
. (2007a), "Decifra-me ou te Devoro! As Finanças e a Sociedade Brasileira". Mana, vol. 13, no 2, pp. 381-410.

. (2007b). “Da Plutocracia à Dominação do Capital Financeiro". Revista Brasileira de Ciências Sociais, vol. 65, pp. 85-107.

GUERREIRO, Gabriela. (2006), “TSE Aprova Pedido para Investigar Lula pelo Caso do Dossiê Antitucano". Folha de S. Paulo, 19 de setembro. Disponível em http://www1.folha.uol.com.br/folha/brasil/ult96u83418.shtml.

GUEX, Sébastien. (2003), “La Politique des Caisses Vides: État, Finances Publiques et Mondialisation". Actes de la Recherche en Sciences Sociales, n으 146-147, pp. 51-61.

GUSFIELD, Joseph R. (1986), Symbolic Crusade: Status Politics and the American Temperance Movement ( $2^{\mathrm{a}}$ ed.). Urbana, University of Illinois Press.

HACKING, Ian. (1983), Representing and Intervening: Introductory Topics in the Philosophy of Natural Science. Cambridge/New York, Cambridge University Press.

. (1990), The Taming of Chance. Cambridge/New York, Cambridge University Press.

(1995), Rewriting the Soul: Multiple Personality and the Sciences of Memory. Princeton, Princeton University Press.

. (1998), Mad Travelers: Reflections on the Reality of Transient Mental Illnesses. Charlottesville, University Press of Virginia.

HUNTER, James Davison. (1991), Culture Wars: The Struggle to Define America. New York, Basic Books.

JAMIESON, Kathleen Hall. (1992), Dirty Politics: Deception, Distraction, and Democracy. New York, Oxford University Press.

. (2000), Everything You Think You Know about Politics... and Why You're Wrong. New York, Basic Books.

JARDIM, Maria A. Chaves. (2007), Entre a Solidariedade e o Risco: Sindicatos e Fundos de Pensão em Tempos de Governo Lula. Tese de doutorado, UFSCar, São Carlos.

KOTCHO, Ricardo. (1976), "Assim Vivem os Nossos Superfuncionários". O Estado de S. Paulo, 1 o de agosto.

. (2005), "Mordomias", in F. Molica (org.), 10 Reportagens que Abalaram a Ditadura. Rio de Janeiro, Record.

LAKOFF, George. (1996), Moral Politics: What Conservatives Know that Liberals Don't. Chicago, The University of Chicago Press.

. (2004), Don't Think of an Elephant! Know your Values and Frame the Debate. White River Junction, Chelsea Green.

LAMUCCI, Sergio. (2006), "Agenda Liberal Afugenta Presidenciáveis". Valor Econômico, 24 de outubro. Disponível em http://clipping.planejamento.gov.br/noticias.asp? notcod $=314064$.

LAWSON-BORDERS, Gracie e KIRK, Rita. (2005), "Blogs in Campaign Communication". American Behavioral Scientist, vol. 49, no 4, pp. 548-559.

LEFEBVRE, Georges. (1988), La Grande Peur de 1789: Suivi de Les Foules Révolutionnaires. Paris, Armand Colin. 


\section{Roberto Grün}

LEONEL, Rita Chaves e LEONEL, Josué. (2003), “Fechado Acordo para Votar Mudança no Sistema Financeiro, Diz Petista". O Estado de S. Paulo, 26 de março.

LEWIS, Bernard. (1986), Semites and Anti-Semites: An Inquiry into Conflict and Prejudice. New York, Norton.

LIMA, Venício A. de. (2006), Mídia: Crise Política e Poder no Brasil. São Paulo, Fundação Perseu Abramo.

LIRIO, Sergio. (2005), “A Orelha Desponta: Repasses Milionários às Empresas de Valério Colocam Dantas na Mira. O PFL Arma a Defesa do Banqueiro". Carta Capital, 3 de agosto.

LUNTZ, Frank I. (1988), Candidates, Consultants and Campaigns: The Style and Substance of American Electioneering. Oxford/New York, Basil Blackwell.

. (2007), Words that Work: It's not What You Say, It's What People Hear. New York, Hyperion.

MACKENZIE, Donald. (2001), Mechanizing Proof: Computing, Risk, and Trust. Cambridge, The MIT Press.

e MILLO, Yuval. (2003), “Constructing a Market, Performing Theory: The Historical Sociology of a Financial Derivatives Exchange". American Journal of Sociology, vol. 109, no 1, pp. 107-145.

MANOFF, Robert Karl e SCHUDSON, Michael (eds.). (1986), Reading the News: A Pantheon Guide to Popular Culture. New York, Pantheon Books.

MARRUS, Michael R. (1972), Les Juifs de France à l'Époque de l'Affaire Dreyfus: l'Assimilation à l'Épreuve. Paris, Calmann-Lévy (prefácio de Pierre Vidal-Naquet).

MARTINS, Ricardo Malavazi. (2006), Petros e a Indústria de Venture Capital e Private Equity (Diversificação e Perspectiva de Longo Prazo). Trabalho apresentado no III Ciclo de Debates Venture Capital no Brasil. Rio de Janeiro, Associação Brasileira de Analistas do Mercado de Capitais - Abamec, 27 de abril.

MAUGER, Gérard. (2006), “Sur la Violence Symbolique”, in H.-P. Müller e Y. Sintomer (eds.), Pierre Bourdieu, Théorie et Pratique Perspectives Franco-Allemandes. Paris, La Découverte, pp. 84-100.

MEDINA, João. (1992), “O Zé Povinho, Caricatura do 'Homo Lusitanus'”, in J. Medina (ed.), Estudos em Homenagem a Jorge Borges de Macedo. Lisboa, Instituto Nacional de Investigação Científica, pp. 445-473.

MEIRELES, A. e KRIEGER, G. (2004), “Bicho na Campanha: Vídeo Mostra Homem de Confiança do Planalto Cobrando Propina e Doações de Campanha de Bicheiro no Rio de Janeiro". Época, 16 de fevereiro.

MENEZES, Maiá et alii. (2006), "TSE Vai Investigar Dossiê contra Tucanos". O Globo, 18 de setembro. Disponível em http://oglobo.globo.com/pais/eleicoes2006/mat/ 2006/09/18/285708214.asp.

MOLICA, Fernando (org.). (2005), 10 Reportagens que Abalaram a Ditadura. Rio de Janeiro, Record.

NASSIF, Luis. (2006), Blog do Nassif. Disponível em http:/ / z001.ig.com.br/ig/04/39/ 946471/blig/luisnassif, acessado em 30/9/2006. 
NOSSA, Leonencio e MONTEIRO, Tânia. (2007), "Lula Acusa FHC de Ter Feito uma Gestão 'Irresponsável'". O Estado de S. Paulo, 6 de janeiro. Disponível em http:/ / www.estado.com.br/editorias/2007/01/06/pol-1.93.11.20070106.12.1.xml.

O ESTADO DE S. PAULO. (2005), “O Brasil dos Fenômenos Editoriais”. São Paulo, 11 de abril.

. (2006), "Eleições 2006 no Estadão: Segundo Turno-Geraldo Alckmin". São Paulo, 26 de outubro.

O GLOBO ONLINE. (2006), "Marco Aurélio Garcia Diz que Postura da Imprensa Gerou Segundo Turno". Disponível em http://oglobo.globo.com/pais/eleicoes2006/ mat/2006/10/02/285930380.asp, 2 de outubro.

(2006), "Debate: Aerolula e 'Lógica da Ética' Dominam Quarto Bloco". Disponível em http://oglobo.globo.com/pais/eleicoes2006/mat/2006/10/08/ 286031200.asp, 8 de outubro.

(2006), “Ética e Escândalos de Corrupção Marcam Primeiro Debate entre Lula e Alckmin". Disponível em http://oglobo.globo.com/pais/eleicoes2006/mat/ 2006/10/08/286030156.asp, 9 de outubro.

OFFERLÉ, Michael. (1994), Sociologie des Groupes d'Intérêt. Paris, Montchrestien.

OLIVEIRA, Flávia. (2000), "Reichstul Anuncia Reestruturação". O Globo, 24 de outubro.

PALHANO, A. (2007), “Novas Oportunidades: Álcool, Combustível (e Investimento) do Futuro". Folha de S. Paulo, 16 de abril. Disponível em http://www1.folha.uol.com. $\mathrm{br} /$ folha/especial/2007/maisdinheiro3/rf1604200708.shtml.

PAUWELS, Louis e BERGIER, Jacques. (1975), O Despertar dos Mágicos: Introdução ao Realismo Fantástico (11a ed.). São Paulo, Difel.

PEREIRA, Raimundo Rodrigues. (2006), “Os Fatos Ocultos”. Carta Capital, no 415, 18 de outubro, pp. 20-27.

PORTER, Theodore M. (1995), Trust in Numbers: The Pursuit of Objectivity in Science and Public Life. Princeton, Princeton University Press.

PRETE, Renata Lo. (2005), "Contei a Lula do 'Mensalão', Diz Deputado". Folha de S. Paulo, 6 de junho. Disponível em http:/ /www1.folha.uol.com.br/folha/brasil / ult96u69403.shtml.

RECONDO, Felipe e SILVEIRA, Rose Ane. (2005), "Sem Provas, Jefferson Confirma 'Mensalão', Poupa Lula e Ataca José Dirceu". Folha de S. Paulo, 15 de junho. Disponível em http:/ /www1.folha.uol.com.br/folha/brasil/ult96u69668.shtml.

RIEDER, Jonathan. (1990), "Rhetoric of Reason, Rhetoric of Passion: Sociolinguistic Aspects of Instrumental and Expressive Rhetorics". Rationality and Society, vol. 2, no 2, pp. 190-213.

e STEINLIGHT, Stephen (eds.). (2003), The Fractious Nation? Unity and Division in Contemporary American Life. Berkeley, University of California Press.

RODRIGUES, Fernando. (2006), “Lula se Beneficia na Situação de Vítima, Diz Publicitário João Santana". Folha de S. Paulo, 5 de novembro. Disponível em http:/ / www1. folha.uol.com.br/folha/brasil/ult96u86328.shtml.

SÁ, Nelson de. (2006), “Toda Mídia Eleições”. Folha de S. Paulo, 2 de novembro. 


\section{Roberto Grün}

SANTOS, Chico. (2007), "Previ Tem Nova Estratégia para seu Private Equity". Valor Econômico, 18 de junho. Disponível em http://www.veteranosdobb.com.br/noticia. php?id_noticia $=348$.

SANTOS, Wanderley Guilherme dos. (2007), “O Capitalismo Venceu! Viva o Socialismo". Valor Econômico, 1o de junho.

SARDENBERG, Carlos Alberto. (2006), “O PSDB Acabou”. O Globo, 2 de novembro.

SCHUDSON, Michael. (1984), Advertising, the Uneasy Persuasion: Its Dubious Impact on American Society. New York, Basic Books.

(1989), "How Culture Works: Perspectives from Media Studies on the Efficacy of Symbols". Theory and Society, vol. 18, no 2, pp. 153-180.

. (1992), Watergate in American Memory: How We Remember, Forget, and Reconstruct the Past. New York, Basic Books.

. (1995), The Power of News. Cambridge, Harvard University Press.

(1998), The Good Citizen: A History of American Civic Life. New York, Martin Kessler Books.

SENADO (2005). Depoimento de Daniel Dantas à Comissão Parlamentar Mista de Inquérito sobre a Compra de Votos. Brasília, 21 de setembro (arquivo da TV Senado).

SHILLER, Robert J. (2003), The New Financial Order: Risk in the 21st Century. Princeton, Princeton University Press.

SHIRLEY, Mary M. (2005), "Why Is Sector Reform so Unpopular in Latin America?". Independent Review, vol. 10, no 2, pp. 195-207.

SMITH, Peter. (2007), "A Public Relations Offensive on the Buy-Out High-Wire". Financial Times, 26 de janeiro.

SORKIN, Andrew Ross e DASH, Eric. (2007), “Private Firms Lure Chief Executives with Top Pay". The New York Times, 8 de janeiro.

SOUZA, Leonardo e ALENCAR, Kennedy. (2005), “Deputado do PFL ‘Clona’ Ação a Favor do Opportunity". Folha de S. Paulo, 23 de agosto.

STERNHELL, Zeev. (1997), La Droite Révolutionnaire, 1885-1914: Les Origines Françaises du Fascisme. Paris, Gallimard.

SUNSTEIN, Cass R. (2007), Republic.com 2.0. Princeton, Princeton University Press.

TAGUIEFF, Pierre-André. (2005), La Foire aux Illuminés: Ésotérisme, Théorie du Complot, Extrémisme. Paris, Mille et Une Nuits.

TEODORO, Plínio. (2006), "Palocci Foi uma Virtude do Governo Lula". O Globo, 6 de novembro.

THE ECONOMIST. (2007), “The Buy-Out Business Is Booming, but Capitalism's New Kings Are Attracting Growing Criticism", no 382, 8 de fevereiro, p. 82.

. (2004), "How Private Equity Is Changing the Business World", no 373, 25 de novembro, p. 10.

THOMPSON, John B. (2000), Political Scandal: Power and Visibility in the Media Age. Cambridge/Malden, Polity Press/Blackwell. 
Escândalos, Marolas e Finanças: Para uma Sociologia da Transformação...

VEJA. (2006), “O Terrorismo do PT”, 18 de outubro. Disponível em http://veja.abril. com.br/181006/p_058.html.

WELCH, Jack e WELCH, Suzy. (2007), "Private Equity Redux". Business Week, 9 de julho. Disponível em http://www.businessweek.com/perm/content/07_28/b4042097. htm.

WILLIAMS, Rhys H. (ed.). (1997), Cultural Wars in American Politics: Critical Reviews of a Popular Myth. New York, Aldine de Gruyter. 


\title{
Roberto Grün
}

\author{
ABSTRACT \\ Scandals, Shock Waves, and Finances: For a Sociology of the Changing \\ Brazilian Economic Environment
}

The political crisis traversed by Lula's first Presidential Administration provided a rare window to analyze the relationship between the world of finance and Brazilian society. The succession of scandals and the reactions to them triggered and unveiled the way in which financial trends depend on the cognitive framings that are produced beyond their boundaries and control. An analysis of how the scandals are produced and the reactions they spark thus shows how society shapes, reinforces, or challenges the conditions in the financial environment, thus highlighting the possibilities and limits of constraints imposed by finances on Brazilian society in the early $21^{\text {st }}$ century.

Key words: sociology of finances; scandals; blogosphere; economic culture; electoral races

\section{RÉSUMÉ}

Scandales, Remous et Finances: Pour une Sociologie de la Transformation de l'Atmosphère Économique

La crise politique que le premier mandat du Président Lula a traversée, est un excellent poste d'observation pour l'analyse des rapports entre le monde des finances et la société où il agit. La suite des scandales et des réactions qu'ils ont provoqués montre clairement comment la marche des finances dépend de contextes cognitifs mis en place hors de leurs frontières et de leur contrôle. L'analyse de la façon dont les scandales se produisent et des réactions qu'ils suscitent montre comment la société fabrique, renforce ou empêche les conditions de dépasser cette activité, marquant ainsi les possibilités et les limites des contraintes que la finance impose à la société brésilienne dans ce début du XXI ${ }^{\mathrm{e}}$ siècle.

Mots-clé: sociologie des finances; scandales; blogosphère; culture économique; luttes électorales 